\title{
Derivation of Residual Radioactive Material Guidelines for 13 Radionuclides Present in Operable Unit IV at Brookhaven National Laboratory, Upton, New York
}

by $\mathrm{E}$. Faillace, M. Nimmagadda, and C. Yu

Environmental Assessment Division,

Argonne National Laboratory, 9700 South Cass Avenue, Argonne, Illinois 60439

December 1994

Work sponsored by United States Department of Energy, Office of Environmental Restoration, Washington, D.C. 


\section{DISCLAIMER}

This report was prepared as an account of work sponsored by an agency of the United States Government. Neither the United States Government nor any agency thereof, nor any of their employees, make any warranty, express or implied, or assumes any legal liability or responsibility for the accuracy, completeness, or usefulness of any information, apparatus, product, or process disclosed, or represents that its use would not infringe privately owned rights. Reference herein to any specific commercial product, process, or service by trade name, trademark, manufacturer, or otherwise does not necessarily constitute or imply its endorsement, recommendation, or favoring by the United States Government or any agency thereof. The views and opinions of authors expressed herein do not necessarily state or reflect those of the United States Government or any agency thereof. 


\section{DISCLAIMER}

Portions of this document may be illegible in electronic image products. Images are produced from the best available original document. 
1 INTRODUCTION AND BRIEF HISTORY $\ldots \ldots \ldots \ldots \ldots \ldots \ldots \ldots \ldots$

1.1 Site Description and Setting $\ldots \ldots \ldots \ldots \ldots \ldots \ldots \ldots \ldots \ldots \ldots \ldots \ldots \ldots \ldots \ldots$

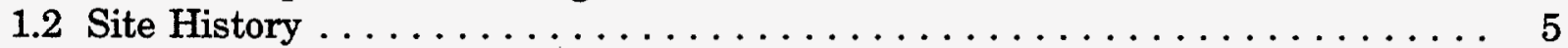

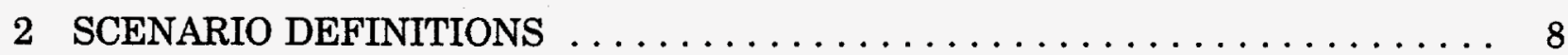

3 DOSE/SOURCE CONCENTRATION RATIOS $\ldots \ldots \ldots \ldots \ldots \ldots \ldots \ldots \ldots$

4 RESIDUAL RADIOACTIVE MATERIAL GUIDELINES $\ldots \ldots \ldots \ldots \ldots \ldots . \ldots 22$

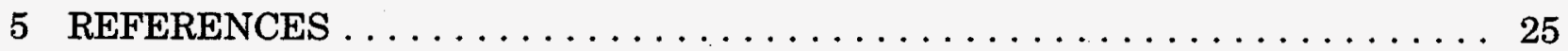

APPENDIX: Scenarios and Parameters Used for the Analysis of

Operable Unit IV at Brookhaven National Laboratory . . . . . . . 27

\section{TABLES}

1 Maximum Soil Concentrations to Remain within the Annual Dose Constraint or Dose Limit for the Four Scenarios $\ldots \ldots \ldots \ldots \ldots \ldots \ldots$

2 Summary of Pathways for Scenarios A, B, C, and D at OU IV $\ldots \ldots \ldots \ldots \ldots$

3 Maximum Dose/Source Concentration Ratios for Americium-241 for Scenarios A, B, C, and D for OU IV .................... 12

4 Maximum Dose/Source Concentration Ratios for Cesium-137 for Scenarios A, B, C, and D for OU IV ................... 13

5 Maximum Dose/Source Concentration Ratios for Cobalt-60 for Scenarios A, B, C, and D for OU IV ................... 13

6 Maximum Dose/Source Concentration Ratios for Europium-152 for Scenarios A, B, C, and D for OU IV .................. 14

7 Maximum Dose/Source Concentration Ratios for Europium-154 for Scenarios A, B, C, and D for OU IV

8 Maximum Dose/Source Concentration Ratios for Europium-155 for Scenarios A, B, C, and D for OU IV 


\section{TABLES (Cont.)}

9 Maximum Dose/Source Concentration Ratios for Plutonium-238

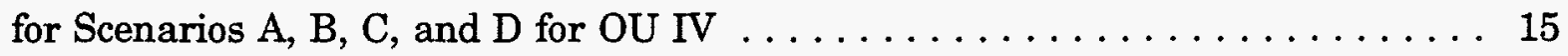

10 Maximum Dose/Source Concentration Ratios for Plutonium-239

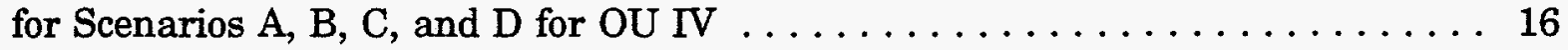

11 Maximum Dose/Source Concentration Ratios for Plutonium-240

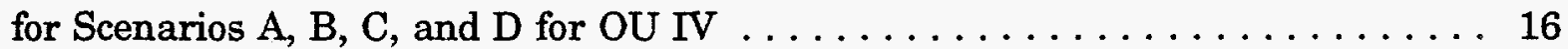

12 Maximum Dose/Source Concentration Ratios for Strontium-90

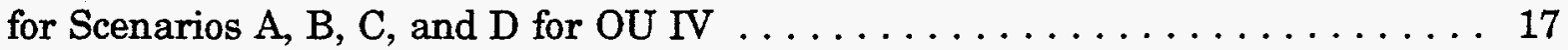

13 Maximum Dose/Source Concentration Ratios for Uranium-234

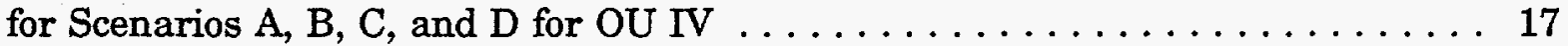

14 Maximum Dose/Source Concentration Ratios for Uranium-235 for Scenarios A, B, C, and D for OU IV . . . . . . . . . . . . . 18

15 Maximum Dose/Source Concentration Ratios for Uranium-238 for Scenarios A, B, C, and D for OU IV . . . . . . . . . . . . . 18

16 Dominant Exposure Pathways for Radionuclides at OU $I V \ldots . . \ldots \ldots \ldots . . . .19$

17 Residual Radioactive Material Guidelines for Radionuclides at OU IV . . . . . . . 22

18 Values for Hot-Spot Multiplication Factors $\ldots \ldots \ldots \ldots \ldots \ldots \ldots \ldots$

19 Residual Radioactive Material Guidelines for Radionuclides at OU IV Assuming a 100-Year Institutional Control Period Following Remedial Action $\ldots \ldots \ldots \ldots \ldots \ldots \ldots \ldots \ldots \ldots$

A.1 Parameters Used in the RESRAD Computer Code for the Analysis of Operable Unit IV at Brookhaven National Laboratory . . . . . . . . . 28

\section{FIGURES}

1 Location of Brookhaven National Laboratory . . . . . . . . . . . . . . . . . . . 4

2 Operable Unit IV at Brookhaven National Laboratory . . . . . . . . . . . . . 6 


\title{
NOTATION
}

The following is a list of the acronyms, initialisms, and units of measure used in this document.

\section{ACRONYMS AND INITIALISMS}

\author{
ALARA as low as reasonably achievable \\ BNL Brookhaven National Laboratory \\ CERCLA Comprehensive Environmental Response, Compensation, and Liability Act \\ CSF Central Steam Facility \\ DOE U.S. Department of Energy \\ EPA U.S. Environmental Protection Agency \\ IAG Interagency Agreement \\ OU Operable Unit \\ RESRAD residual radioactive material guideline computer code \\ SAIC Science Applications International Corp. \\ TBCs to-be-considereds
}

\section{UNITS OF MEASURE}

$\begin{array}{ll}\mathrm{Ci} & \text { curie(s) } \\ \mathrm{cm} & \text { centimeter(s) } \\ \mathrm{cm}^{3} & \text { cubic centimeter(s) } \\ \mathrm{d} & \text { day(s) } \\ \mathrm{g} & \text { gram(s) } \\ \mathrm{h} & \text { hour(s) } \\ \mathrm{km} & \text { kilometer(s) } \\ \mathrm{km}^{2} & \text { square kilometer(s) } \\ \mathrm{L} & \text { liter(s) } \\ \mathrm{m} & \text { meter(s) } \\ \mathrm{m}^{2} & \text { square meter(s) } \\ \mathrm{mL} & \text { milliliter(s) } \\ \mathrm{pCi} & \text { picocurie(s) } \\ \mathrm{yr} & \text { year(s) }\end{array}$




\title{
DERIVATION OF RESIDUAL RADIOACTIVE MATERLAL GUIDELINES \\ FOR 13 RADIONUCLIDES PRESENT IN OPERABLE UNIT IV AT \\ BROOKHAVEN NATIONAL LABORATORY, UPTON, NEW YORK
}

by

\author{
E.R. Faillace, M. Nimmagadda, and C. Yu
}

\section{SUMMARY}

Residual radioactive material guidelines for 13 radionuclides (americium-241; cobalt-60; cesium-137; europium-152, -154, and -155; plutonium-238, -239, and -240; strontium-90; and uranium-234, -235, and -238) were derived for Operable Unit (OU) IV at Brookhaven National Laboratory. This site has been identified for remedial action under the Comprehensive Environmental Response, Compensation, and Liability Act of 1980, as amended by the Superfund Amendments and Reauthorization Act of 1986. Single-nuclide guidelines were derived on the basis of the requirement that the 50-year committed effective dose equivalent to a hypothetical individual who lives or works in the immediate vicinity of OU IV should not exceed a dose constraint of $30 \mathrm{mrem} / \mathrm{yr}$ following remedial action for the current use and plausible future use scenarios or a dose limit of $100 \mathrm{mrem} / \mathrm{yr}$ for plausible but less likely future use scenarios (Yu et al. 1993b). The U.S. Department of Energy (DOE) residual radioactive material guideline computer code, RESRAD, was used in this evaluation; RESRAD implements the methodology described in the DOE manual for determining residual radioactive material guidelines.

Four potential scenarios were considered; each assumed that, for a period of 1,000 years following remedial action, the site would be used without radiological restrictions. The four scenarios varied with regard to the type of site use, time spent at the site, and sources of food consumed.

Table 1 presents the results of the evaluation; it shows the maximum soil concentrations of each radionuclide at which the dose constraint or dose limit would not be exceeded for each scenario. The four scenarios considered are A, industrial (current use); B, recreational (plausible future use); $\mathrm{C}$, residential (plausible future use); D, farmer (plausible but less likely future use). These guidelines were calculated as single-radionuclide guidelines on the basis of a dose constraint of $30 \mathrm{mrem} / \mathrm{yr}$ for Scenarios A, B, and C and a dose limit of $100 \mathrm{mrem} / \mathrm{yr}$ for Scenario D ( $\mathrm{Yu}$ et al. 1993b). In setting the actual residual radioactive material guidelines for OU IV, DOE will apply the as-low-as-reasonably-achievable (ALARA) policy to the decision-making process, along with other factors such as whether a particular scenario is reasonable and appropriate. 
TABLE 1 Maximum Soil Concentrations to Remain within the Annual Dose Constraint or Dose Limit for the Four Scenarios ${ }^{a}$

\begin{tabular}{lcccc}
\hline & \multicolumn{4}{c}{$\begin{array}{c}\text { Soil Concentrations (pCi/g) at which the Dose } \\
\text { Constraint or Limit Will Not Be Exceeded }\end{array}$} \\
\cline { 2 - 5 } \multicolumn{1}{c}{ Radionuclide } & Scenario A & Scenario B & Scenario C & Scenario D \\
\hline & 160 & 340 & 52 & 110 \\
Americium-241 & 29 & 65 & 9.6 & 30 \\
Cesium-137 & 6.4 & 15 & 2.1 & 7.0 \\
Cobalt-60 & 15 & 35 & 4.9 & 16 \\
Europium-152 & 13 & 32 & 4.4 & 15 \\
Europium-154 & 870 & 2,100 & 290 & 970 \\
Europium-155 & 190 & 410 & 63 & 130 \\
Plutonium-238 & 170 & 370 & 56 & 120 \\
Plutonium-239 & 170 & 370 & 56 & 120 \\
Plutonium-240 & 20,000 & 200 & 41 & 25 \\
Strontium-90 & 800 & 1,700 & 54 & 160 \\
Uranium-234 & 140 & 330 & 33 & 95 \\
Uranium-235 & 500 & 1,100 & 55 & 170 \\
Uranium-238 & & & & \\
\hline
\end{tabular}

a Scenario A, industrial use; Scenario B, recreational use; Scenario C, residential use; Scenario $\mathrm{D}$, farming use.

b The dose constraint is $30 \mathrm{mrem} / \mathrm{yr}$ for Scenarios A, B, and C; the dose limit is $100 \mathrm{mrem} / \mathrm{yr}$ for Scenario D. 


\section{INTRODUCTION AND BRIEF HISTORY}

Brookhaven National Laboratory (BNL) is located in Upton, New York. In 1988, the U.S. Department of Energy (DOE) identified the Building 650 Sump Outfall Area of Operable Unit (OU) IV as an area of known radiological contamination. On December 21, 1989, the site was identified for remedial action under the Comprehensive Environmental Response, Compensation, and Liability Act (CERCLA) National Priorities List under Section 120 of CERCLA (SAIC 1992). CERCLA was established in 1980 and amended by the Superfund Amendments and Reauthorization Act of 1986. An Interagency Agreement (IAG) for the environmental restoration of the BNL site was negotiated among DOE, the U.S. Environmental Protection Agency, and the New York State Department of Environmental Conservation. The IAG became effective in May 1992.

The site will be remediated to comply with federal and state applicable or relevant and appropriate requirements (ARARs), which are promulgated regulations, and "to be considereds" (TBCs), which include standards, guidance, and policy that are not promulgated. This report follows the guidelines established in DOE Order 5400.5 (DOE 1990) for the derivation of site-specific residual radioactive material guidelines. The IAG parties have agreed on the use of the DOE residual radioactive material computer code, RESRAD (Yu et al. 1993b) to derive residual radionuclide guidelines on a site-specific basis. This report presents the guidelines for 13 radionuclides (americium-241; cobalt-60; cesium-137; europium-152, -154, and -155; plutonium-238, -239, and -240; strontium-90; and uranium-234, -235, and -238) derived for the Reclamation Facility Building 650 Sump and Sump Outfall Area of OU IV at BNL on the basis of a dose constraint of $30 \mathrm{mrem} / \mathrm{yr}$ for the current use and likely future use scenarios and a dose limit of $100 \mathrm{mrem} / \mathrm{yr}$ for less likely but plausible future use scenarios (Yu et al. 1993b). The dose constraint of $30 \mathrm{mrem} / \mathrm{yr}$ is not currently required under DOE Order 5400.5; it allows for dose contributions from other sources of radiation. The final guidelines will be negotiated and agreed upon by the IAG parties.

\subsection{SITE DESCRIPTION AND SETTING}

BNL is located about $100 \mathrm{~km}$ east of New York City, close to the geographical center of Suffolk County on Long Island (Figure 1). BNL covers approximately $20 \mathrm{~km}^{2}$ and is roughly rectangular in shape. The developed portion of the site at BNL includes the principal facilities, which are located near the center of the site on relatively high ground. These facilities are contained in an area of approximately $3.6 \mathrm{~km}^{2}$, of which $2.0 \mathrm{~km}^{2}$ was originally developed for Army use. Outlying facilities occupy approximately $2.2 \mathrm{~km}^{2}$ and include an apartment area, biology field, the Hazardous Waste Management Facility, the Sewage Treatment Plant, fire breaks, and the Former Landfill Area. BNL is owned by DOE and operated by Associated Universities, Inc. (SAIC 1992).

The site terrain is gently rolling, with elevations varying between 12 to $37 \mathrm{~m}$ above sea level. The land lies on the western rim of the shallow Peconic River watershed, with a 


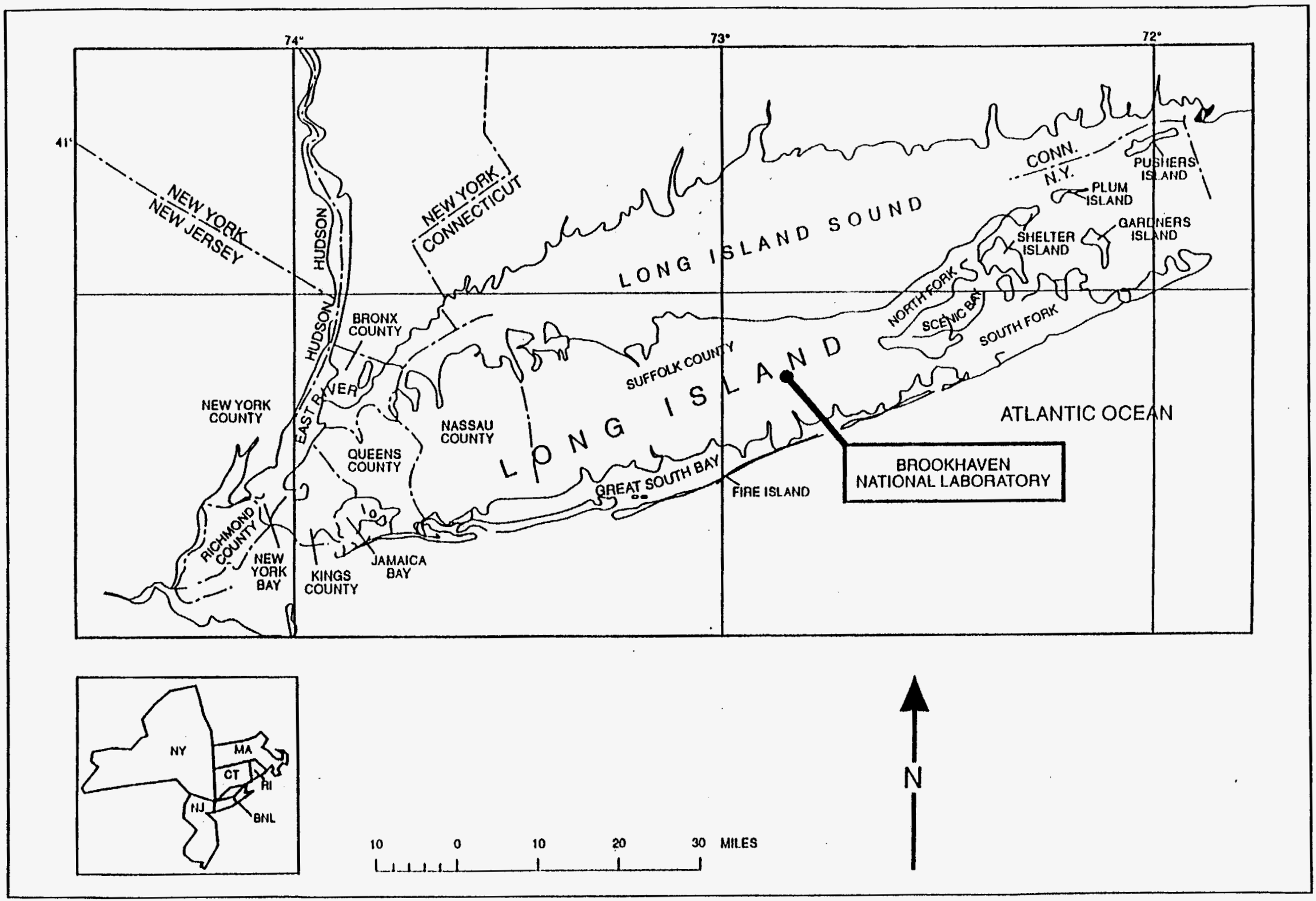

A

FIGURE 1 Location of Brookhaven National Laboratory 
tributary of the river rising in marshy areas in the northern section of the tract. The majority of the site, approximately $75 \%$ of its total area, is largely wooded (IT 1991). The topsoil is from 0 to $35 \mathrm{~cm}$ thick and is underlain by layers of silty sand, sand, and sandy loam with a mean bulk density of $2.0 \mathrm{~g} / \mathrm{cm}^{3}$ (BNL 1994). The average total and effective porosities of the soil are 0.33 and 0.24 , respectively, and the average hydraulic vertical and horizontal conductivities are 5,000 and $20,000 \mathrm{~m} / \mathrm{yr}$, respectively (Warren et al. 1963). Borehole logs indicate that the depth to the water table ranges from 9.8 to $12.5 \mathrm{~m}$ (BNL 1994). The average hydraulic gradient is 0.001 , with water moving northwest to southeast (Warren et al. 1963). Because of the gentle topography and porous soils, very little runoff or open water is on-site (IT 1991). No natural surface water bodies occur within the limits of OU IV; however, surface water runoff along developed areas is diverted into storm sewers (IT 1991). Storm water in the vicinity of the Central Steam Facility (CSF) is diverted to a sewer outfall located east of the CSF. Precipitation on Long Island averages approximately $110 \mathrm{~cm} / \mathrm{yr}$. Approximately $46.6 \%$ of the annual freshwater budget is lost to evapotranspiration (IT 1991). Because most ( $>95 \%$ ) of the stream water is derived from groundwater seepage, direct runoff of precipitation to the Atlantic Ocean or Long Island Sound is negligible. Nearly all precipitation not consumed by evapotranspiration or runoff recharges the groundwater reservoir. The recharge is estimated to be approximately $60 \mathrm{~cm} / \mathrm{yr}$ (SAIC 1992). Groundwater eventually discharges either directly into the ocean or into the rivers flowing southward.

OU IV is located on the east-central edge of the developed portion of the site (Figure 2) and encompasses:

- CSF,

- Reclamation Facility Building 650 Sump and Sump Outfall Area, and

- Recharge Basin HO.

The CSF is located between North Sixth Street, Seventh Street, Brookhaven Avenue, and Cornell Avenue. This area consists of approximately $53,000 \mathrm{~m}^{2}$, divided equally between developed and undeveloped land. The Building 650 Sump is north of the CSF, approximately $30 \mathrm{~m}$ north of Cornell Avenue. The Building 650 Sump Outfall Area is located approximately $30 \mathrm{~m}$ north of Cornell Avenue and approximately $300 \mathrm{~m}$ northeast of Building 650 . The Sump Outfall is a natural wooded depression, approximately 27 by $27 \mathrm{~m}$, and is bounded by dirt roads. Recharge Basin $\mathrm{HO}$ is located approximately $76 \mathrm{~m}$ northeast of the Building 650 Sump Outfall.

\subsection{SITE HISTORY}

The BNL site was formerly occupied by the U.S. Army as Camp Upton in World Wars I and II; it was transferred to the Atomic Energy Commission in 1947, to the Energy 


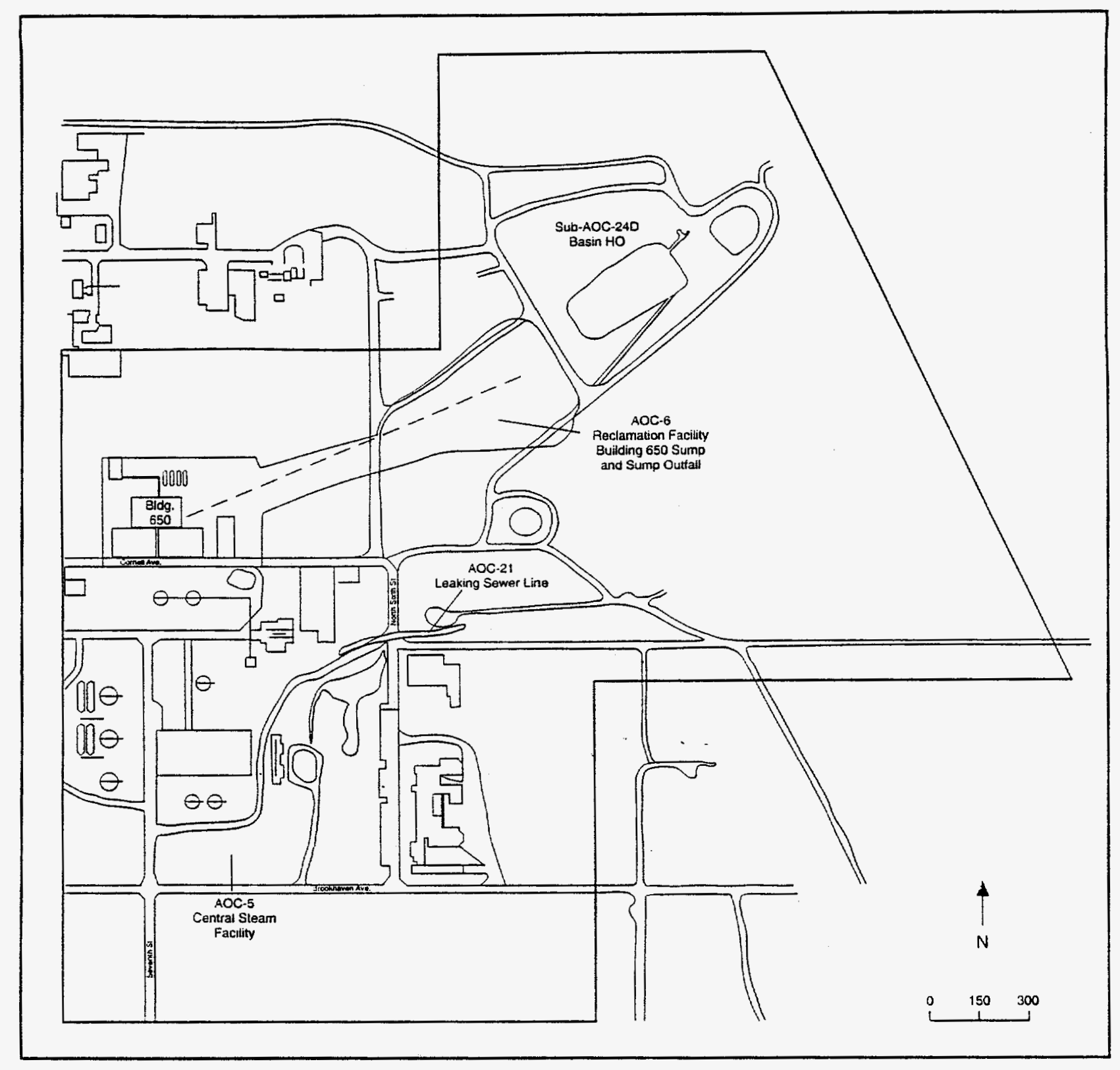

FIGURE 2 Operable Unit IV at Brookhaven National Laboratory

Research and Development Administration in 1975, and to DOE in 1977. BNL's functions include the design, construction, and operation of large research facilities, such as particle accelerators, nuclear reactors, and synchrotron storage rings, to carry out research in (1) high-energy and nuclear physics; (2) material, chemical, and biological sciences; and (3) energy-related life and environmental sciences. The scientific, operational, and support activities at BNL result in generation of solid, liquid, and gaseous waste materials. Certain areas of the site have become radiologically and chemically contaminated from spills and other uncontrolled releases. In particular, one of the three areas included in OU IV was found to be radiologically contaminated: the Building 650 Sump and Sump Outfall Area (SAIC 1992). This area is the focus of this report. 
Building 650 was constructed to serve as a decontamination facility for the removal of radiation from clothing and heavy equipment. Therefore, Building 650 was designed to perform wash operations both outdoors and inside the building. These operations date back to at least 1959; the construction of underground storage tanks began in 1962 . The facility was operational until 1990.

Liquid waste from the laundry facility was contained in four underground storage tanks located north of the building. Two 7,600-L holding tanks (tanks 1 and 2) were designated for $\mathrm{D}$-waste (gross beta $>90 \mathrm{pCi} / \mathrm{mL}$ ). Typically, the water was deemed clean enough to be routed to two 11,000-L underground storage tanks (tanks 3 and 4), located adjacent to tanks 1 and 2. Tanks 3 and 4 were designated for $\mathrm{F}$-waste containment (gross beta concentration $<90 \mathrm{pCi} / \mathrm{mL}$ ). The $\mathrm{D}$ - and $\mathrm{F}$-wastes in the tanks were removed approximately three and two times a year, respectively. Approximately six drums of sludge waste were removed from tanks 1 and 2 in 1983. In 1990, IT Corporation analyzed sludges and residual sludge from tanks 3 and 4 (IT 1991).

Building 650 also served as a decontamination facility for equipment contaminated with radioactive material. Beginning in approximately 1959, equipment was steam cleaned on a $9-\mathrm{m}$ by $9-\mathrm{m}$ concrete pad behind the north side of the building. Contaminated water flowed into a drum in the middle of the sloping pad known as the Building $650 \mathrm{Sump}$. From 1959 to 1969, site operators believed that effluent from the decontamination pad was piped to the Sewage Treatment Plant; however, in late 1969, $5 \mathrm{Ci}$ of tritium was accidentally released into the Building 650 Sump but no tritium was subsequently detected at the Sewage Treatment Plant (SAIC 1992). An investigation into the incident revealed that the drainage pipe from the outdoor concrete pad behind Building 650 led to a natural depression in a wooded area about $300 \mathrm{~m}$ northeast of Building 650 , rather than to either the sanitary system or to a waste holding tank as had been previously assumed. The practice of washing radioactive equipment on the concrete pad was discontinued after this incident.

Between 1971 and 1973, eight monitoring wells were installed in the Sump Outfall Area. Groundwater samples were collected annually, in at least some of the wells, through 1985. In 1988, DOE identified the Building 650 Sump Outfall Area as a source of groundwater contamination, a potential direct contact hazard, and an area of known radiological contamination of an undefined nature and extent (SAIC 1992).

The results of soil samples collected and analyzed in 1993 and 1994 as part of the Remedial Investigation at OU IV (BNL 1994) indicated elevated concentrations of americium-241; cobalt-60; cesium-137; europium-152, -154, and -155; plutonium-238, -239, and -240; strontium-90; and uranium-234, -235 , and -238 in the soils behind Building 650 (near the outdoor decontamination pad and the four underground storage tanks and in the Sump Outfall Area). Contamination above background has been detected to a depth of $7.9 \mathrm{~m}$ (Nealy 1994). 


\section{SCENARIO DEFINITIONS}

Four potential exposure scenarios were considered for OU IV. All scenarios assumed that, at some time within 1,000 years, the site would be released for use without radiological restrictions following remedial action. These scenarios were developed on the basis of discussions with site personnel to ensure consistency with the site baseline report (SAIC 1992).

Scenario A (the expected scenario) assumed industrial use of the site. Under this scenario, a hypothetical individual was assumed to work in the area of the site 8 hours per day ( 6 hours outdoors and 2 hours indoors), 5 days per week, 50 weeks per year. Therefore, in 1 year, the worker was assumed to spend $17 \%$ of the time working outdoors at the site, $6 \%$ working indoors at the site, and $77 \%$ away from the site. It was assumed that the worker did not ingest water, plant foods, or fish obtained from the decontaminated area or meat or milk from livestock raised in the decontaminated area.

Scenario B (a plausible future use scenario) assumed recreational use of the site. Under this scenario, it was assumed that, at some time in the future, the whole site would be transformed into a public recreational park or forest preserve and a hypothetical individual would spend 15 hours per week, 50 weeks per year, in the decontaminated area of the park. Therefore, in 1 year, this generic recreationist was assumed to spend $9 \%$ of the time in the decontaminated area and $91 \%$ away from the site. It was assumed that the recreationist does not ingest water or plant foods obtained from the decontaminated area or meat or milk from livestock raised in the decontaminated area. Also, it was assumed that any fish or other aquatic food consumed by the recreationist is not obtained from the site. However, because deer and other game are abundant on Long Island, it was assumed that some of the meat consumed by the recreationist is obtained from hunting animals that reside on the site.

Scenario C (another plausible future use scenario) assumed that the site would be developed as a residential area where a hypothetical resident would spend $50 \%$ of the time indoors in the decontaminated area, $25 \%$ outdoors in the decontaminated area, and $25 \%$ away from the site. The resident was assumed to grow fruits and vegetables in a garden on the decontaminated site. Drinking water and irrigation water were assumed to be provided by an on-site well. It was assumed that the resident does not raise livestock in the decontaminated area. It was also assumed that any fish or other aquatic food consumed by the resident is not obtained from the site.

Scenario $D$ (a plausible but unlikely future use scenario) assumed that, at some time in the future, the whole site would be transformed into a farm and, in 1 year, a hypothetical farmer would spend $50 \%$ of the time indoors in the decontaminated area, $25 \%$ outdoors in the decontaminated area, and $25 \%$ away from the site. The farmer was assumed to grow produce on the decontaminated site and to raise livestock for meat and milk. The farmer's drinking, irrigation, and livestock water supply was assumed to come from an on-site well. As in 
Scenario C, it was assumed that fish and other aquatic food consumed by the farmer are not obtained from the site.

All pathways considered for Scenarios A, B, C, and D are summarized in Table 2. Potential radiation doses resulting from the following eight exposure pathways were analyzed:

- Direct exposure to external gamma radiation from decontaminated soil material,

- Internal radiation from inhalation of contaminated dust,

- Internal radiation from inhalation of radon progeny,

- Internal radiation from ingestion of plant foods grown in the decontaminated area and irrigated with water from local groundwater wells,

- Internal radiation from ingestion of meat obtained from livestock fed with fodder grown in the decontaminated area and with water drawn from inside the area,

- Internal radiation from ingestion of milk obtained from livestock fed with fodder grown in the decontaminated area and with water drawn from inside the area.

- Internal radiation from ingestion of water drawn from inside the area, and

- Internal radiation from ingestion of on-site soil.

TABLE 2 Summary of Pathways for Scenarios A, B, C, and D at OU IV

\begin{tabular}{|c|c|c|c|c|}
\hline Pathway & $\begin{array}{c}\text { Scenario A } \\
\text { (Worker) }\end{array}$ & $\begin{array}{c}\text { Scenario B } \\
\text { (Recreationist) }\end{array}$ & $\begin{array}{l}\text { Scenario C } \\
\text { (Resident) }\end{array}$ & $\begin{array}{c}\text { Scenario D } \\
\text { (Farmer) }\end{array}$ \\
\hline External gamma exposure & Yes & Yes & Yes & Yes \\
\hline Inhalation of dust & Yes & Yes & Yes & Yes \\
\hline Inhalation of radon ${ }^{a}$ & Yes & Yes & Yes & Yes \\
\hline Ingestion of plant foods & No & No & Yes & Yes \\
\hline Ingestion of meat & No & Yes & No & Yes \\
\hline Ingestion of milk & No & No & No & Yes \\
\hline Ingestion of fish & No & No & No & No \\
\hline Ingestion of soil & Yes & Yes & Yes & Yes \\
\hline Ingestion of water & No & No & Yes & Yes \\
\hline
\end{tabular}

a Applies only to uranium-234, uranium-238, plutonium-238, and plutonium-240. 
When the RESRAD computer code (Yu et al. 1993b) was used to calculate potential radiation doses, the following conservative assumptions were made:

- An area of $3,100 \mathrm{~m}^{2}$ is homogeneously contaminated to a thickness of $7.9 \mathrm{~m}$ (Nealy 1994).

- During 1 year, the industrial worker spends 1,500 hours (17\%) outdoors at the site, 500 hours (6\%) indoors at the site, and 6,760 hours (77\%) away from the site; the recreationist spends 750 hours (9\%) per year outdoors on-site; and the resident/farmer spends 4,380 hours (50\%) indoors, 2,190 hours (25\%) outdoors in the decontaminated area, and 2,190 hours $(25 \%)$ away from the site.

- The walls, floors, and foundation of the house or office building reduce external exposure by $20 \%$.

- The indoor dust level in the house or office building is $40 \%$ of the outdoor dust level (Yu et al. 1993b).

- The annual intake of soil is $36.5 \mathrm{~g} / \mathrm{yr}$ for the receptor in Scenario A. For Scenarios B, C, and D, the annual intake of soil is $43.8 \mathrm{~g} / \mathrm{yr}$ to account for the higher ingestion rates by children (EPA 1990). RESRAD modifies these intake rates to account for on-site occupancy.

- An individual's annual intake of leafy vegetables and other produce is 14 and $160 \mathrm{~kg} / \mathrm{yr}$, respectively (Yu et al. 1993b). Of the plant food diet consumed by the resident and the farmer, $10 \%$ and $50 \%$, respectively, are grown in the decontaminated area. Neither the worker nor the recreationist consumes these plant foods.

- The decontaminated area is large enough to grow $15.5 \%$ of the forage needed for raising livestock in the decontaminated area to produce sufficient meat and milk for the farmer. The worker, recreationist, and resident do not consume this meat or milk. Game animals living on the decontaminated site constitute $10 \%$ of the meat diet of a recreationist-hunter.

- The precipitation and irrigation rates are 110 and $26 \mathrm{~cm} / \mathrm{yr}$, respectively. Approximately $20 \%$ of the precipitation is lost by runoff and $46 \%$ of the remainder is lost by evapotranspiration, resulting in a net infiltration rate of $62 \mathrm{~cm} / \mathrm{yr}$ (Penny 1994).

- The sandy soils in the decontaminated area have a density of $2 \mathrm{~g} / \mathrm{cm}^{3}$ and a total and effective porosity of 0.33 and 0.24 , respectively. The vertical hydraulic conductivity in the unsaturated zone is $5,000 \mathrm{~m} / \mathrm{yr}$. The hydraulic conductivity and hydraulic gradient in the saturated zone 
are $20,000 \mathrm{~m} / \mathrm{yr}$ and 0.001 , respectively. The "b" parameter used by RESRAD to calculate the saturation ratio in the unsaturated zones is 4.9 (Yu et al. 1993b; Penny 1994).

- Site-specific distribution coefficients used to calculate radionuclide leaching and transport in groundwater have not been measured at OU IV. Where available, generic distribution coefficients for sandy soils from Yu et al. (1993a) are used. If not available, the soil/plant transfer factor correlation method is used by RESRAD to estimate the distribution coefficients.

- The resident and farmer drink $700 \mathrm{~L} / \mathrm{yr}(2 \mathrm{~L} / \mathrm{d}$ for $350 \mathrm{~d} / \mathrm{yr})$ of water drawn from an on-site well (EPA 1990).

- After remedial action, no cover material is placed over the decontaminated area.

- All other parameters are set to the RESRAD defaults. 


\section{DOSE/SOURCE CONCENTRATION RATIOS}

The RESRAD computer code Version 5.191 (Yu et al. 1993b) was used to calculate the dose/source concentration ratio $D S R_{p}(t)$ for pathway $p$ at time $t$ after remedial action. The time frame considered in this analysis was 1,000 years. Radioactive decay was considered in deriving the dose/source concentration ratios. The various parameters used in the RESRAD code for this analysis of Scenarios A, B, C, and D are listed in the Appendix. The maximum dose/source concentration ratios for all pathways are presented for each of the 13 radionuclides in Tables 3 through 15.

In Scenarios A and B, the maximum dose/source concentration ratios occur at time zero (immediately after remedial action) for all 13 radionuclides. This is also the case in Scenarios $C$ and $D$ for all radionuclides except the uranium isotopes. For the uranium isotopes, the maximum occurs at 400 years in the future because of contaminant migration in the groundwater.

Table 16 indicates the pathway with the highest dose contribution for each radionuclide and each scenario. For americium-241, the dominant pathway is dust inhalation in Scenarios A, B, and C and ingestion of produce in Scenario D. For cobalt-60, cesium-137, and the europium isotopes, the dominant pathway in all four scenarios is direct external gamma exposure. For the plutonium isotopes, the dominant pathway is dust inhalation in Scenarios A, B, and C and ingestion of produce grown on-site in Scenario D.

TABLE 3 Maximum Dose/Source Concentration Ratios for Americium-241 for Scenarios A, B, C, and D for OU IV

\begin{tabular}{lcccc}
\hline & \multicolumn{4}{c}{ Maximum $\begin{array}{c}\text { Dose/Source Concentration Ratios } \\
(\mathrm{mrem} / \mathrm{yr}) /(\mathrm{pC} / \mathrm{g})\end{array}$} \\
\cline { 2 - 5 } \multicolumn{1}{c}{ Pathway } & Scenario A & Scenario B & Scenario C & Scenario D \\
\cline { 2 - 5 } External exposure & $9.6 \times 10^{-3}$ & $4.0 \times 10^{-3}$ & $2.9 \times 10^{-2}$ & $2.9 \times 10^{-2}$ \\
Inhalation of dust & $1.4 \times 10^{-1}$ & $6.5 \times 10^{-2}$ & $3.2 \times 10^{-1}$ & $3.2 \times 10^{-1}$ \\
Ingestion of plant foods & $\mathrm{NA}^{\mathrm{b}}$ & $\mathrm{NA}$ & $7.9 \times 10^{-2}$ & $3.9 \times 10^{-1}$ \\
Ingestion of meat & $\mathrm{NA}$ & $\begin{array}{c}8.1 \times 10^{-4} \\
\mathrm{NA}\end{array}$ & $\mathrm{NA}$ & $1.3 \times 10^{-3}$ \\
Ingestion of milk & $\mathrm{NA}$ & $\mathrm{NA}$ & $\mathrm{NA}$ & $7.1 \times 10^{-5}$ \\
Ingestion of soil & $3.8 \times 10^{-2}$ & $1.8 \times 10^{-2}$ & $1.5 \times 10^{-1}$ & $1.5 \times 10^{-1}$ \\
Ingestion of water & $\mathrm{NA}$ & $\mathrm{NA}$ & 0 & 0 \\
& & & & 0 \\
Total & $1.9 \times 10^{-1}$ & $8.7 \times 10^{-2}$ & $5.8 \times 10^{-1}$ & $9.0 \times 10^{-1}$ \\
\hline
\end{tabular}

a All values are reported to two significant figures. Maximum dose/source concentration ratios would occur immediately following remedial action.

b NA = Not applicable. 
TABLE 4 Maximum Dose/Source Concentration Ratios for Cesium-137 for Scenarios A, B, C, and D for OU IV

\begin{tabular}{lcccc}
\hline & \multicolumn{4}{c}{ Maximum $\begin{array}{c}\text { Dose/Source Concentration Ratios } \\
(\mathrm{mrem} / \mathrm{yr}) /(\mathrm{pCi} / \mathrm{g})\end{array}$} \\
\cline { 2 - 5 } \multicolumn{1}{c}{ Pathway } & Scenario A & Scenario B & Scenario C & Scenario D \\
\cline { 2 - 5 } External exposure & 1.0 & $4.3 \times 10^{-1}$ & 3.1 & 3.1 \\
Inhalation of dust & $8.6 \times 10^{-6}$ & $4.0 \times 10^{-6}$ & $2.0 \times 10^{-5}$ & $2.0 \times 10^{-5}$ \\
Ingestion of plant foods & $\mathrm{NA}^{\mathrm{b}}$ & $\mathrm{NA}$ & $3.5 \times 10^{-2}$ & $1.7 \times 10^{-1}$ \\
Ingestion of meat & $\mathrm{NA}$ & $3.0 \times 10^{-2}$ & $\mathrm{NA}$ & $4.7 \times 10^{-2}$ \\
Ingestion of milk & $\mathrm{NA}$ & $\mathrm{NA}$ & $\mathrm{NA}$ & $1.5 \times 10^{-2}$ \\
Ingestion of soil & $4.2 \times 10^{-4}$ & $2.0 \times 10^{-4}$ & $1.6 \times 10^{-3}$ & $1.6 \times 10^{-3}$ \\
Ingestion of water & $\mathrm{NA}$ & $\mathrm{NA}$ & 0 & 0 \\
& & & & 3.1 \\
Total & 1.0 & $4.6 \times 10^{-1}$ & & 3.3 \\
\hline
\end{tabular}

a All values are reported to two significant figures. Maximum dose/source concentration ratios would occur immediately following remedial action.

b $\mathrm{NA}=$ Not applicable.

TABLE 5 Maximum Dose/Source Concentration Ratios for Cobalt-60 for Scenarios A, B, C, and D for OU IV

\begin{tabular}{lcccc}
\hline & \multicolumn{4}{c}{ Maximum $\begin{array}{c}\text { Dose/Source Concentration Ratios } \\
(\mathrm{mrem} / \mathrm{yr}) /(\mathrm{pCi} / \mathrm{g})\end{array}$} \\
\cline { 2 - 5 } \multicolumn{1}{c}{ Pathway } & Scenario A & Scenario B & Scenario C & Scenario D \\
\cline { 2 - 5 } & 4.7 & 1.9 & $1.4 \times 10^{1}$ & $1.4 \times 10^{1}$ \\
External exposure & $4.0 \times 10^{-5}$ & $1.9 \times 10^{-5}$ & $9.4 \times 10^{-5}$ & $9.4 \times 10^{-5}$ \\
Inhalation of dust & $\mathrm{NA}^{\mathrm{b}}$ & $\mathrm{NA}$ & $3.6 \times 10^{-2}$ & $1.8 \times 10^{-1}$ \\
Ingestion of plant foods & $\mathrm{NA}$ & $1.9 \times 10^{-2}$ & $\mathrm{NA}$ & $3.0 \times 10^{-2}$ \\
Ingestion of meat & $\mathrm{NA}$ & $\mathrm{NA}$ & $\mathrm{NA}$ & $3.6 \times 10^{-3}$ \\
Ingestion of milk & $2.2 \times 10^{-4}$ & $1.0 \times 10^{-4}$ & $8.5 \times 10^{-4}$ & $8.5 \times 10^{-4}$ \\
Ingestion of soil & $\mathrm{NA}$ & $\mathrm{NA}$ & 0 & 0 \\
Ingestion of water & & & & 0 \\
& 4.7 & 2.0 & $1.4 \times 10^{1}$ & $1.4 \times 10^{1}$ \\
\hline
\end{tabular}

a All values are reported to two significant figures. Maximum dose/source concentration ratios would occur immediately following remedial action.

b NA = Not applicable. 
TABLE 6 Maximum Dose/Source Concentration Ratios for Europium-152 for Scenarios A, B, C, and D for OU IV

\begin{tabular}{|c|c|c|c|c|}
\hline \multirow[b]{2}{*}{ Pathway } & \multicolumn{4}{|c|}{$\begin{array}{c}\text { Maximum Dose/Source Concentration Ratios }{ }^{\mathrm{a}} \\
(\mathrm{mrem} / \mathrm{yr}) /(\mathrm{pCi} / \mathrm{g})\end{array}$} \\
\hline & Scenario A & Scenario B & Scenario C & Scenario D \\
\hline External exposure & 2.1 & $8.5 \times 10^{-1}$ & 6.1 & 6.1 \\
\hline Inhalation of dust & $5.9 \times 10^{-5}$ & $2.7 \times 10^{-5}$ & $1.4 \times 10^{-4}$ & $1.4 \times 10^{-4}$ \\
\hline Ingestion of plant foods & $N^{b}$ & NA & $2.6 \times 10^{-4}$ & $1.3 \times 10^{-3}$ \\
\hline Ingestion of meat & $\mathrm{NA}$ & $5.1 \times 10^{-5}$ & NA & $7.8 \times 10^{-5}$ \\
\hline Ingestion of milk & NA & NA & NA & $1.1 \times 10^{-6}$ \\
\hline Ingestion of soil & $5.0 \times 10^{-5}$ & $2.4 \times 10^{-5}$ & $2.0 \times 10^{-4}$ & $2.0 \times 10^{-4}$ \\
\hline Ingestion of water & NA & $\mathrm{NA}$ & 0 & 0 \\
\hline Total & 2.1 & $8.5 \times 10^{-1}$ & 6.1 & 6.1 \\
\hline
\end{tabular}

a All values are reported to two significant figures. Maximum dose/source concentration ratios would occur immediately following remedial action.

b $\mathrm{NA}=$ Not applicable.

TABLE 7 Maximum Dose/Source Concentration Ratios for Europium-154 for Scenarios A, B, C, and D for OU IV

\begin{tabular}{|c|c|c|c|c|}
\hline \multirow[b]{2}{*}{ Pathway } & \multicolumn{4}{|c|}{$\begin{array}{l}\text { Maximum Dose/Source Concentration Ratios }{ }^{\mathrm{a}} \\
(\mathrm{mrem} / \mathrm{yr}) /(\mathrm{pCi} / \mathrm{g})\end{array}$} \\
\hline & Scenario A & Scenario B & Scenario C & Scenario D \\
\hline External exposure & 2.3 & $9.4 \times 10^{-1}$ & 6.8 & 6.8 \\
\hline Inhalation of dust & $7.0 \times 10^{-5}$ & $3.2 \times 10^{-5}$ & $1.6 \times 10^{-4}$ & $1.6 \times 10^{-4}$ \\
\hline Ingestion of plant foods & $\mathrm{NA}^{\mathrm{b}}$ & NA & $4.0 \times 10^{-4}$ & $2.0 \times 10^{-3}$ \\
\hline Ingestion of meat & $\mathrm{NA}$ & $7.6 \times 10^{-5}$ & NA & $1.2 \times 10^{-4}$ \\
\hline Ingestion of milk & $\mathrm{NA}$ & NA & NA & $1.7 \times 10^{-6}$ \\
\hline Ingestion of soil & $7.6 \times 10^{-5}$ & $3.6 \times 10^{-5}$ & $3.0 \times 10^{-4}$ & $3.0 \times 10^{-4}$ \\
\hline Ingestion of water & NA & NA & 0 & 0 \\
\hline Total & 2.3 & $9.4 \times 10^{-1}$ & 6.8 & 6.8 \\
\hline
\end{tabular}

a All values are reported to two significant figures. Maximum dose/source concentration ratios would occur immediately following remedial action.

b $\mathrm{NA}=$ Not applicable. 
TABLE 8 Maximum Dose/Source Concentration Ratios for Europium-155 for Scenarios A, B, C, and D for OU IV

\begin{tabular}{|c|c|c|c|c|}
\hline \multirow[b]{2}{*}{ Pathway } & \multicolumn{4}{|c|}{$\begin{array}{c}\text { Maximum Dose/Source Concentration Ratios } \\
\text { (mrem/yr)/(pCi/g) }\end{array}$} \\
\hline & Scenario A & Scenario B & Scenario C & Scenario D \\
\hline $\begin{array}{l}\text { External exposure } \\
\text { Inhalation of dust } \\
\text { Ingestion of plant foods } \\
\text { Ingestion of meat } \\
\text { Ingestion of milk } \\
\text { Ingestion of soil } \\
\text { Ingestion of water }\end{array}$ & $\begin{array}{l}3.5 \times 10^{-2} \\
1.0 \times 10^{-5} \\
\mathrm{NA}^{\mathrm{b}} \\
\mathrm{NA} \\
\mathrm{NA} \\
1.1 \times 10^{-5} \\
\mathrm{NA}\end{array}$ & $\begin{array}{l}1.4 \times 10^{-2} \\
4.9 \times 10^{-6} \\
\mathrm{NA} \\
1.1 \times 10^{-5} \\
\mathrm{NA} \\
5.1 \times 10^{-6} \\
\mathrm{NA}\end{array}$ & $\begin{array}{l}1.0 \times 10^{-1} \\
2.4 \times 10^{-5} \\
5.6 \times 10^{-5} \\
\mathrm{NA} \\
\mathrm{NA} \\
4.3 \times 10^{-5} \\
0\end{array}$ & $\begin{array}{l}1.0 \times 10^{-1} \\
2.4 \times 10^{-5} \\
2.8 \times 10^{-4} \\
1.7 \times 10^{-5} \\
2.4 \times 10^{-7} \\
4.3 \times 10^{-5} \\
0\end{array}$ \\
\hline Total & $3.5 \times 10^{-2}$ & $1.4 \times 10^{-2}$ & $1.0 \times 10^{-1}$ & $1.0 \times 10^{-1}$ \\
\hline $\begin{array}{l}\text { All values are reported } \\
\text { concentration ratios w } \\
\text { b NA = Not applicable. }\end{array}$ & $\begin{array}{l}\text { two signific } \\
\text { d occur imm }\end{array}$ & centration 1 & $\begin{array}{l}\text { mum dose/so } \\
\text { remedial act }\end{array}$ & lium-238 \\
\hline & \multicolumn{4}{|c|}{$\begin{array}{l}\text { Maximum Dose/Source Concentration Ratios }{ }^{\mathrm{a}} \\
(\mathrm{mrem} / \mathrm{yr}) /(\mathrm{pCi} / \mathrm{g})\end{array}$} \\
\hline Pathway & Scenario A & Scenario B & Scenario C & Scenario D \\
\hline $\begin{array}{l}\text { External exposure } \\
\text { Inhalation of dust } \\
\text { Inhalation of radon } \\
\text { Ingestion of plant foods } \\
\text { Ingestion of meat } \\
\text { Ingestion of milk } \\
\text { Ingestion of soil } \\
\text { Ingestion of water }\end{array}$ & $\begin{array}{c}2.3 \times 10^{-4} \\
1.2 \times 10^{-1} \\
0 \\
\mathrm{NA}^{b} \\
\mathrm{NA} \\
\mathrm{NA} \\
3.2 \times 10^{-2} \\
\mathrm{NA}\end{array}$ & $\begin{array}{c}9.7 \times 10^{-5} \\
5.7 \times 10^{-2} \\
0 \\
\mathrm{NA} \\
1.4 \times 10^{-3} \\
\mathrm{NA} \\
1.5 \times 10^{-2} \\
\mathrm{NA}\end{array}$ & $\begin{array}{l}7.0 \times 10^{-4} \\
2.9 \times 10^{-1} \\
0 \\
6.7 \times 10^{-2} \\
\mathrm{NA} \\
\mathrm{NA} \\
1.2 \times 10^{-1} \\
0\end{array}$ & $\begin{array}{l}7.0 \times 10^{-4} \\
2.9 \times 10^{-1} \\
0 \\
3.3 \times 10^{-1} \\
2.1 \times 10^{-3} \\
3.0 \times 10^{-5} \\
1.2 \times 10^{-1} \\
0\end{array}$ \\
\hline Total & $1.6 \times 10^{-1}$ & $7.4 \times 10^{-2}$ & $4.8 \times 10^{-1}$ & $7.5 \times 10^{-1}$ \\
\hline
\end{tabular}

a All values are reported to two significant figures. Maximum dose/source concentration ratios would occur immediately following remedial action.

b $\mathrm{NA}=$ Not applicable. 
TABLE 10 Maximum Dose/Source Concentration Ratios for Plutonium-239 for Scenarios A, B, C, and D for OU IV

\begin{tabular}{|c|c|c|c|c|}
\hline \multirow[b]{2}{*}{ Pathway } & \multicolumn{4}{|c|}{$\begin{array}{l}\text { Maximum Dose/Source Concentration Ratios }{ }^{\mathrm{a}} \\
(\mathrm{mrem} / \mathrm{yr}) /(\mathrm{pCi} / \mathrm{g})\end{array}$} \\
\hline & Scenario A & Scenario B & Scenario C & Scenario D \\
\hline $\begin{array}{l}\text { External exposure } \\
\text { Inhalation of dust } \\
\text { Ingestion of plant foods } \\
\text { Ingestion of meat } \\
\text { Ingestion of milk } \\
\text { Ingestion of soil } \\
\text { Ingestion of water }\end{array}$ & $\begin{array}{l}1.4 \times 10^{-4} \\
1.4 \times 10^{-1} \\
\mathrm{NA}^{\mathrm{b}} \\
\mathrm{NA} \\
\mathrm{NA} \\
3.6 \times 10^{-2} \\
\mathrm{NA}\end{array}$ & $\begin{array}{l}5.6 \times 10^{-5} \\
6.3 \times 10^{-2} \\
\mathrm{NA} \\
1.5 \times 10^{-3} \\
\mathrm{NA} \\
1.7 \times 10^{-2} \\
\mathrm{NA}\end{array}$ & $\begin{array}{l}4.0 \times 10^{-4} \\
3.2 \times 10^{-1} \\
7.5 \times 10^{-2} \\
\mathrm{NA} \\
\mathrm{NA} \\
1.4 \times 10^{-1} \\
0\end{array}$ & $\begin{array}{c}4.0 \times 10^{-4} \\
3.2 \times 10^{-1} \\
3.8 \times 10^{-1} \\
2.4 \times 10^{-3} \\
3.4 \times 10^{-5} \\
1.4 \times 10^{-1} \\
0\end{array}$ \\
\hline Total & $1.7 \times 10^{-1}$ & $8.2 \times 10^{-2}$ & $5.3 \times 10^{-1}$ & $8.4 \times 10^{-1}$ \\
\hline \multicolumn{5}{|c|}{$\begin{array}{l}\text { All values are reported to two significant figures. Maximum dose/source } \\
\text { concentration ratios would occur immediately following remedial action. } \\
\text { b NA = Not applicable. } \\
\text { TABLE } 11 \text { Maximum Dose/Source Concentration Ratios for Plutonium-240 } \\
\text { for Scenarios A, B, C, and D for OU IV }\end{array}$} \\
\hline & \multicolumn{4}{|c|}{$\begin{array}{c}\text { Maximum Dose/Source Concentration Ratios }{ }^{\mathrm{a}} \\
(\mathrm{mrem} / \mathrm{yr}) /(\mathrm{pCi} / \mathrm{g})\end{array}$} \\
\hline Pathway & Scenario A & Scenario B & Scenario C & Scenario D \\
\hline $\begin{array}{l}\text { External exposure } \\
\text { Inhalation of dust } \\
\text { Inhalation of radon } \\
\text { Ingestion of plant foods } \\
\text { Ingestion of meat } \\
\text { Ingestion of milk } \\
\text { Ingestion of soil } \\
\text { Ingestion of water }\end{array}$ & $\begin{array}{c}2.2 \times 10^{-4} \\
1.4 \times 10^{-1} \\
0 \\
\mathrm{NA}^{\mathrm{b}} \\
\mathrm{NA} \\
\mathrm{NA} \\
3.6 \times 10^{-2} \\
\mathrm{NA}\end{array}$ & $\begin{array}{c}9.3 \times 10^{-5} \\
6.4 \times 10^{-2} \\
0 \\
\mathrm{NA} \\
1.5 \times 10^{-3} \\
\mathrm{NA} \\
1.7 \times 10^{-2} \\
\mathrm{NA}\end{array}$ & $\begin{array}{c}6.7 \times 10^{-4} \\
3.2 \times 10^{-1} \\
0 \\
7.5 \times 10^{-2} \\
\mathrm{NA} \\
\mathrm{NA} \\
1.4 \times 10^{-1} \\
0\end{array}$ & $\begin{array}{l}6.7 \times 10^{-4} \\
3.2 \times 10^{-1} \\
0 \\
3.8 \times 10^{-1} \\
2.4 \times 10^{-3} \\
3.4 \times 10^{-5} \\
1.4 \times 10^{-1} \\
0\end{array}$ \\
\hline Total & $1.7 \times 10^{-1}$ & $8.2 \times 10^{-2}$ & $5.4 \times 10^{-1}$ & $8.4 \times 10^{-1}$ \\
\hline
\end{tabular}

a All values are reported to two significant figures. Maximum dose/source concentration ratios would occur immediately following remedial action.

b $\mathrm{NA}=$ Not applicable. 
TABLE 12 Maximum Dose/Source Concentration Ratios for Strontium-90 for Scenarios $A, B, C$, and $D$ for OU IV

\begin{tabular}{lcccc}
\hline & \multicolumn{4}{c}{ Maximum $\begin{array}{c}\text { Dose/Source Concentration Ratios } \\
(\mathrm{mrem} / \mathrm{yr}) /(\mathrm{pCi} / \mathrm{g})\end{array}$} \\
\cline { 2 - 5 } \multicolumn{1}{c}{ Pathway } & Scenario A & Scenario B & Scenario C & Scenario D \\
\cline { 2 - 5 } External exposure & 0 & 0 & 0 & 0 \\
Inhalation of dust & $3.5 \times 10^{-4}$ & $1.6 \times 10^{-4}$ & $8.1 \times 10^{-4}$ & $8.1 \times 10^{-4}$ \\
Ingestion of plant foods & $\mathrm{NA}$ & $\mathrm{NA}$ & $7.3 \times 10^{-1}$ & 3.7 \\
Ingestion of meat & $\mathrm{NA}$ & $1.5 \times 10^{-1}$ & $\mathrm{NA}$ & $2.3 \times 10^{-1}$ \\
Ingestion of milk & $\mathrm{NA}$ & $\mathrm{NA}$ & $\mathrm{NA}$ & $6.8 \times 10^{-2}$ \\
Ingestion of soil & $1.2 \times 10^{-3}$ & $5.5 \times 10^{-4}$ & $4.6 \times 10^{-3}$ & $4.6 \times 10^{-3}$ \\
Ingestion of water & $\mathrm{NA}$ & $\mathrm{NA}$ & 0 & 0 \\
& & & & 0 \\
Total & $1.5 \times 10^{-3}$ & $1.5 \times 10^{-1}$ & $7.4 \times 10^{-1}$ & 4.0 \\
\hline
\end{tabular}

a All values are reported to two significant figures. Maximum dose/ source concentration ratios would occur immediately following remedial action.

b $\mathrm{NA}=$ Not applicable.

TABLE 13 Maximum Dose/Source Concentration Ratios for Uranium-234 for Scenarios A, B, C, and D for OU IV

Maximum Dose/Source Concentration Ratios ${ }^{\mathrm{a}}$ $(\mathrm{mrem} / \mathrm{yr}) /(\mathrm{pCi} / \mathrm{g})$

\begin{tabular}{lcccc}
\cline { 2 - 5 } \multicolumn{1}{c}{ Pathway } & Scenario $\mathrm{A}^{\mathrm{b}}$ & Scenario $^{\mathrm{b}}$ & Scenario $\mathrm{C}^{\mathrm{c}}$ & Scenario $\mathrm{D}^{\mathrm{c}}$ \\
\hline External exposure & $2.5 \times 10^{-4}$ & $1.0 \times 10^{-4}$ & $2.9 \times 10^{-3}$ & $2.9 \times 10^{-3}$ \\
Inhalation of dust & $3.5 \times 10^{-2}$ & $1.6 \times 10^{-2}$ & $5.3 \times 10^{-2}$ & $5.3 \times 10^{-2}$ \\
Inhalation of radon & 0 & 0 & $3.0 \times 10^{-2}$ & $3.0 \times 10^{-2}$ \\
Ingestion of plant foods & $\mathrm{NA}^{\mathrm{d}}$ & $\mathrm{NA}$ & $1.4 \times 10^{-2}$ & $7.1 \times 10^{-2}$ \\
Ingestion of meat & $\mathrm{NA}$ & $3.7 \times 10^{-4}$ & $\mathrm{NA}$ & $8.4 \times 10^{-4}$ \\
Ingestion of milk & $\mathrm{NA}$ & $\mathrm{NA}$ & $\mathrm{NA}$ & $2.5 \times 10^{-3}$ \\
Ingestion of soil & $2.2 \times 10^{-3}$ & $1.0 \times 10^{-3}$ & $5.6 \times 10^{-3}$ & $5.6 \times 10^{-3}$ \\
Ingestion of water & $\mathrm{NA}$ & $\mathrm{NA}$ & $4.5 \times 10^{-1}$ & $4.5 \times 10^{-1}$ \\
& & & & \\
Total & $3.7 \times 10^{-2}$ & $1.8 \times 10^{-2}$ & $5.5 \times 10^{-1}$ & $6.1 \times 10^{-1}$ \\
\hline
\end{tabular}

a All values are reported to two significant figures.

b Maximum ratios would occur immediately following remedial action.

c Maximum ratios would occur 400 years following remedial action.

d NA = Not applicable. 
TABLE 14 Maximum Dose/Source Concentration Ratios for Uranium-235 for Scenarios A, B, C, and D for OU IV

\begin{tabular}{|c|c|c|c|c|}
\hline \multirow[b]{2}{*}{ Pathway } & \multicolumn{4}{|c|}{$\begin{array}{c}\text { Maximum Dose/Source Concentration Ratios }^{a} \\
(\mathrm{mrem} / \mathrm{yr}) /(\mathrm{pCi} / \mathrm{g})\end{array}$} \\
\hline & Scenario $\mathrm{A}^{\mathrm{b}}$ & Scenario $\mathrm{B}^{\mathrm{b}}$ & Scenario $C^{c}$ & Scenario $D^{c}$ \\
\hline External exposure & $1.8 \times 10^{-1}$ & $7.6 \times 10^{-2}$ & $3.6 \times 10^{-1}$ & $3.6 \times 10^{-1}$ \\
\hline Inhalation of dust & $3.2 \times 10^{-2}$ & $1.5 \times 10^{-2}$ & $7.9 \times 10^{-2}$ & $7.9 \times 10^{-2}$ \\
\hline Ingestion of plant foods & $\mathrm{NA}^{\mathrm{d}}$ & NA & $3.0 \times 10^{-2}$ & $1.5 \times 10^{-1}$ \\
\hline Ingestion of meat & $\mathrm{NA}$ & $3.6 \times 10^{-4}$ & NA & $5.1 \times 10^{-3}$ \\
\hline Ingestion of milk & NA & NA & NA & $2.4 \times 10^{-3}$ \\
\hline Ingestion of soil & $2.1 \times 10^{-3}$ & $9.9 \times 10^{-4}$ & $1.1 \times 10^{-2}$ & $1.1 \times 10^{-2}$ \\
\hline Ingestion of water & NA & NA & $4.3 \times 10^{-1}$ & $4.3 \times 10^{-1}$ \\
\hline Total & $2.2 \times 10^{-1}$ & $9.2 \times 10^{-2}$ & $9.2 \times 10^{-1}$ & 1.0 \\
\hline
\end{tabular}

a All values are reported to two significant figures.

b Maximum ratios would occur immediately following remedial action.

c Maximum ratios would occur 400 years following remedial action.

d NA = Not applicable.

TABLE 15 Maximum Dose/Source Concentration Ratios for Uranium-238 for Scenarios A, B, C, and D for OU IV

\begin{tabular}{lcccc}
\hline & \multicolumn{4}{c}{ Maximum $\begin{array}{c}\text { Dose/Source Concentration Ratios } \\
(\mathrm{mrem} / \mathrm{yr}) /(\mathrm{pCi} / \mathrm{g})\end{array}$} \\
\cline { 2 - 5 } \multicolumn{1}{c}{ Pathway } & ${\text { Scenario } \mathrm{A}^{\mathrm{b}}}^{\mathrm{a}}$ & Scenario B $^{\mathrm{b}}$ & Scenario $\mathrm{C}^{\mathrm{c}}$ & Scenario $^{\mathrm{c}}$ \\
\hline External exposure & $2.6 \times 10^{-2}$ & $1.1 \times 10^{-2}$ & $5.0 \times 10^{-2}$ & $5.0 \times 10^{-2}$ \\
Inhalation of dust & $3.2 \times 10^{-2}$ & $1.5 \times 10^{-2}$ & $4.8 \times 10^{-2}$ & $4.8 \times 10^{-2}$ \\
Inhalation of radon & 0 & 0 & $1.1 \times 10^{-5}$ & $1.1 \times 10^{-5}$ \\
Ingestion of plant foods & $\mathrm{NA}^{\mathrm{d}}$ & $\mathrm{NA}$ & $1.4 \times 10^{-2}$ & $6.7 \times 10^{-2}$ \\
Ingestion of meat & $\mathrm{NA}$ & $3.6 \times 10^{-4}$ & $\mathrm{NA}$ & $7.9 \times 10^{-4}$ \\
Ingestion of milk & $\mathrm{NA}$ & $\mathrm{NA}$ & $\mathrm{NA}$ & $2.4 \times 10^{-3}$ \\
Ingestion of soil & $2.1 \times 10^{-3}$ & $9.9 \times 10^{-4}$ & $5.3 \times 10^{-3}$ & $5.3 \times 10^{-3}$ \\
Ingestion of water & $\mathrm{NA}$ & $\mathrm{NA}$ & $4.3 \times 10^{-1}$ & $4.3 \times 10^{-1}$ \\
& & & & \\
Total & $6.1 \times 10^{-2}$ & $2.7 \times 10^{-2}$ & $5.5 \times 10^{-1}$ & $6.0 \times 10^{-1}$ \\
\hline
\end{tabular}

a All values are reported to two significant figures.

b Maximum ratios would occur immediately following remedial action.

c Maximum ratios would occur 400 years following remedial action.

d $\mathrm{NA}=$ Not applicable. 
TABLE 16 Dominant Exposure Pathways for Radionuclides at OU IV

\begin{tabular}{|c|c|c|c|c|}
\hline \multirow[b]{2}{*}{ Radionuclide } & \multicolumn{4}{|c|}{ Dominant Pathways } \\
\hline & Scenario A & Scenario B & Scenario C & Scenario D \\
\hline $\begin{array}{l}\text { Americium-241 } \\
\text { Cobalt-60 } \\
\text { Cesium-137 } \\
\text { Europium-152 } \\
\text { Europium-154 } \\
\text { Europium-155 } \\
\text { Plutonium-238 } \\
\text { Plutonium-239 } \\
\text { Plutonium-240 } \\
\text { Strontium-90 } \\
\text { Uranium-234 } \\
\text { Uranium-235 } \\
\text { Uranium-238 }\end{array}$ & $\begin{array}{l}\text { Dust }^{\mathbf{a}} \\
\text { Direct }^{\mathrm{c}} \\
\text { Direct } \\
\text { Direct } \\
\text { Direct } \\
\text { Direct } \\
\text { Dust } \\
\text { Dust } \\
\text { Dust } \\
\text { Soil } \\
\text { Dust } \\
\text { Direct } \\
\text { Dust }\end{array}$ & $\begin{array}{l}\text { Dust } \\
\text { Direct } \\
\text { Direct } \\
\text { Direct } \\
\text { Direct } \\
\text { Direct } \\
\text { Dust } \\
\text { Dust } \\
\text { Dust } \\
\text { Meat } \\
\text { Dust } \\
\text { Direct } \\
\text { Dust }\end{array}$ & $\begin{array}{l}\text { Dust } \\
\text { Direct } \\
\text { Direct } \\
\text { Direct } \\
\text { Direct } \\
\text { Direct } \\
\text { Dust } \\
\text { Dust } \\
\text { Dust } \\
\text { Produce } \\
\text { Water } \\
\text { Water } \\
\text { Water }\end{array}$ & $\begin{array}{l}\text { Produce }^{b} \\
\text { Direct } \\
\text { Direct } \\
\text { Direct } \\
\text { Direct } \\
\text { Direct } \\
\text { Produce } \\
\text { Produce } \\
\text { Produce } \\
\text { Produce } \\
\text { Water } \\
\text { Water } \\
\text { Water }\end{array}$ \\
\hline $\begin{array}{ll}\text { a } & \text { Dust = Inhala } \\
\text { b } & \text { Produce = Ing } \\
\text { c } & \text { Direct = Exte } \\
\text { d } & \text { Soil = Ingesti } \\
\text { - } & \text { Meat = Ingest } \\
\text { f } & \text { Water = Inges }\end{array}$ & $\begin{array}{l}\text { al gamma exp } \\
\text { of on-site soil } \\
\text { of meat fron } \\
\text { on of water fr }\end{array}$ & $\begin{array}{l}\text { dst. } \\
\text { grown on-sit } \\
\text { sure from on }\end{array}$ & site soil. & \\
\hline
\end{tabular}

For strontium-90, ingestion of soil and ingestion of meat are the dominant pathways in Scenarios A and B, respectively; the ingestion of produce is the dominant pathway in Scenarios C and D.

In Scenarios A and B, the dominant pathway is dust inhalation for uranium-234 and uranium-238 and direct external gamma exposure for uranium-235; the dominant pathway in Scenarios $C$ and $D$ is water ingestion for the uranium isotopes. The summation of $D S R_{i p}(t)$ for all pathways $p$ is the $D S R_{i}(t)$ for the $i^{\text {th }}$ isotope,

$$
D S R_{i}(t)=\sum_{p} D S R_{i p}(t)
$$

The total dose/source concentration ratios for each radionuclide (Tables 3 through 15) were used to determine the allowable residual radioactivities for these radionuclides at OU IV. 
Uncertainty in the derivation of dose/source concentration ratios arises from the distribution of possible input parameter values, as well as uncertainty in the conceptual model used to represent the site. Depending on the radionuclide and scenario, different parameters affect the results in each case.

For radionuclides with external gamma exposure as the dominant pathway, uncertainty in the shielding factor for indoor occupancy and the time fractions for indoor and outdoor occupancy will result in uncertainty in the calculated dose/source ratios. Increasing the overall occupancy will result in higher dose rates. Increasing the indoor occupancy relative to the outdoor occupancy will result in lower dose rates. When used in conjunction with indoor occupancy, increasing the indoor shielding will also reduce dose rates. The thickness of the contaminated zone is important for only a relatively thin layer of contamination; beyond $1 \mathrm{~m}$, the actual thickness of the contaminated zone will not affect the estimated dose rates.

Parameters that affect the dust inhalation pathway include the inhalation rate, the mass loading of dust in air, the occupancy fractions for each scenario, and the indoor shielding factor. The first three parameters are directly proportional to the dose rate. Changes in the indoor occupancy and shielding fractions have the same effect on the dust inhalation pathway as they do on the external exposure pathway. As with the external exposure pathway, the thickness of the contaminated zone is important for only a relatively thin layer of contamination; a thickness greater than the mixing layer of $15 \mathrm{~cm}$ will not affect the estimated dose rates.

For the soil ingestion pathway, the critical parameters are the soil ingestion rate and the on-site occupancy factor. The strontium-90 dose/source concentration ratio for Scenario A is almost directly proportional to variations in either of these parameters.

Ingestion of produce is the dominant pathway in Scenario $D$ for americium-241, the plutonium isotopes, and strontium-90, and is the dominant pathway in Scenario C for strontium-90. The assumed consumption rates and contaminated fractions of produce have a significant effect on the maximum dose/source concentration ratios. Because the latter occur at time zero, variations in the irrigation rate and other parameters used in the leaching and groundwater transport models do not affect the dose contributions from this pathway. The soil/plant transfer factors used are the RESRAD defaults; actual transfer factors may be different for the sandy soils present at BNL. The depth of roots will affect the dose calculations only when the thickness of the contaminated zone is less than the root depth.

Ingestion of meat is only important in deriving the dose/source concentration ratio for strontium-90 in Scenario B, where it is the dominant pathway. The contribution from this pathway is almost certainly overestimated because it assumes that the animal obtains all of its food from the $3,100 \mathrm{~m}^{2}$ that constitute the decontaminated area. In the case of deer, it is unlikely that the animals would remain confined for a long time to such a relatively small area. Other factors that may affect the meat ingestion pathway are fodder/meat transfer factors, fodder intake rates, and meat consumption rates. For all of these, the RESRAD default values are used and are derived for beef cattle. 
A number of uncertainties are associated with the water ingestion pathway because it affects maximum dose/source ratios that are estimated to occur some time in the future. Besides parameter uncertainties, there are model uncertainties; RESRAD uses a onedimensional groundwater model and assumes that a well is located at the downgradient edge of the decontaminated zone. Both Scenarios $\mathrm{C}$ and $\mathrm{D}$ assume that the source of water is this downgradient well; it is more likely that the water would be provided by a municipal source. Two parameters that have a significant impact on the dose calculations are the choice of radionuclide distribution coefficients and the thickness of the contaminated zone. The distribution coefficients selected for these calculations are geometric mean values of distribution coefficients for sandy soils obtained from the literature. The range of values for some of these coefficients spans several orders of magnitude. The value selected for the contaminated zone thickness is very conservative, and the actual dose/source concentration ratios will probably be lower than those calculated by RESRAD. The dose calculations will also be to some extent sensitive to all the other parameters that affect leaching and radionuclide transport in groundwater. Finally, the water ingestion dose will be directly proportional to the consumption rate of water.

The RESRAD default values were used when no site-specific data were available. These default values are based on national average or reasonable maximum values. In addition, the contaminated zone thickness of $7.9 \mathrm{~m}$ that was selected to derive the dose/source concentration ratios is based on the assumption that the soil is uniformly contaminated to that depth. In reality, most of the contamination has been detected in the top $60 \mathrm{~cm}(2 \mathrm{ft})$ of soil and is not dispersed uniformly throughout the site. Although the conceptual model used for OU IV assumes no uncontaminated cover is present, any amount of cover material would reduce the estimated dose/source ratios for all radionuclides. Therefore, the calculated dose/source ratios are conservative. 


\section{RESIDUAL RADIOACTIVE MATERLAL GUIDELINES}

The residual radioactive material guideline is the concentration of residual radioactive material that can remain in a decontaminated area and still allow use of the area without radiological restrictions. The single-radionuclide residual radioactive material guideline $G_{i}$ for radionuclides at OU IV can be calculated as

$$
G_{i}=H_{E V} D S R_{i},
$$

where $D S R_{i}$ is the total dose/source concentration ratio listed in Tables 3 through 15 . The dose limit, $H_{E L}$, used to derive the residual radioactive material guideline is $30 \mathrm{mrem} / \mathrm{yr}$ for the current use and plausible future use scenarios and $100 \mathrm{mrem} / \mathrm{yr}$ for all other plausible but less likely future use scenarios ( $\mathrm{Yu}$ et al. 1993b). The calculated residual radioactive material guidelines for the 13 radionuclides at OU IV are presented in Table 17. The derived guidelines are linearly proportional to the dose limit used in the calculation.

The sum-of-fractions rule applies when the derived radionuclide guidelines are implemented for decontamination of a site. That is, the summation of the fractions of

TABLE 17 Residual Radioactive Material Guidelines for Radionuclides at OU IV

\begin{tabular}{lcccc}
\hline & \multicolumn{4}{c}{ Guidelines $^{\mathrm{a}}(\mathrm{pCi} / \mathrm{g})$} \\
\cline { 2 - 5 } \multicolumn{1}{c}{ Radionuclide } & Scenario A & Scenario $^{\mathrm{b}}$ & Scenario C $^{\mathrm{b}}$ & Scenario $\mathrm{D}^{\mathrm{c}}$ \\
\hline Americium-241 & $1.6 \times 10^{2}$ & $3.4 \times 10^{2}$ & $5.2 \times 10^{1}$ & $1.1 \times 10^{2}$ \\
Cesium-137 & $2.9 \times 10^{1}$ & $6.5 \times 10^{1}$ & 9.6 & $3.0 \times 10^{1}$ \\
Cobalt-60 & 6.4 & $1.5 \times 10^{1}$ & 2.1 & 7.0 \\
Europium-152 & $1.5 \times 10^{1}$ & $3.5 \times 10^{1}$ & 4.9 & $1.6 \times 10^{1}$ \\
Europium-154 & $1.3 \times 10^{1}$ & $3.2 \times 10^{1}$ & 4.4 & $1.5 \times 10^{1}$ \\
Europium-155 & $8.7 \times 10^{2}$ & $2.1 \times 10^{3}$ & $2.9 \times 10^{2}$ & $9.7 \times 10^{2}$ \\
Plutonium-238 & $1.9 \times 10^{2}$ & $4.1 \times 10^{2}$ & $6.3 \times 10^{1}$ & $1.3 \times 10^{2}$ \\
Plutonium-239 & $1.7 \times 10^{2}$ & $3.7 \times 10^{2}$ & $5.6 \times 10^{1}$ & $1.2 \times 10^{2}$ \\
Plutonium-240 & $1.7 \times 10^{2}$ & $3.7 \times 10^{2}$ & $5.6 \times 10^{1}$ & $1.2 \times 10^{2}$ \\
Strontium-90 & $2.0 \times 10^{4}$ & $2.0 \times 10^{2}$ & $4.1 \times 10^{1}$ & $2.5 \times 10^{1}$ \\
Uranium-234 & $8.0 \times 10^{2}$ & $1.7 \times 10^{3}$ & $5.4 \times 10^{1}$ & $1.6 \times 10^{2}$ \\
Uranium-235 & $1.4 \times 10^{2}$ & $3.3 \times 10^{2}$ & $3.3 \times 10^{1}$ & $9.5 \times 10^{1}$ \\
Uranium-238 & $5.0 \times 10^{2}$ & $1.1 \times 10^{3}$ & $5.5 \times 10^{1}$ & $1.7 \times 10^{2}$ \\
\hline
\end{tabular}

a All values are reported to two significant figures.

b Based on a dose constraint of $30 \mathrm{mrem} / \mathrm{yr}$.

c Based on a dose limit of $100 \mathrm{mrem} / \mathrm{yr}$. 
radionuclide concentrations $S_{i}$ remaining on-site, averaged over an area of $100 \mathrm{~m}^{2}$ and a depth of $15 \mathrm{~cm}$ and divided by their guidelines $G_{i}$, should not be greater than unity, or

$$
\sum_{i} S_{i} / G_{i} \leq 1
$$

The derived guidelines for OU IV are single-radionuclide guidelines for a large homogeneously contaminated area. For a small, isolated area of contamination ("a hot-spot") the allowable concentration that can remain on-site may be higher than the homogeneous guideline, depending on the size of the contaminated area and in accordance with the values given in Table 18.

With a few exceptions, the highest dose rates occur immediately following remedial action. In these cases, the most restrictive residual radioactive material guidelines apply to time zero and increase over time when the site is not immediately released for unrestricted use. When drinking water is the dominant pathway, the soil guidelines reach a minimum value at some time in the future and then increase again. If credit is taken for an institutional control period following remedial action, the applicable residual radioactive material guidelines may be higher than if the site were released for unrestricted use immediately following remedial action. Table 19 shows the guidelines that apply to an institutional control period of 100 years following remedial action, after which the site would be released for unrestricted use.

In setting the actual residual radioactive material guidelines at OU IV, DOE will apply the as low as reasonably achievable (ALARA) policy to the decisionmaking process, along with other factors such as whether a particular scenario is reasonable and appropriate. The final guidelines will be negotiated and agreed upon by the IAG parties.

TABLE 18 Values for Hot-Spot Multiplication Fac̣tors

\begin{tabular}{cc}
$\begin{array}{c}\text { Hot Spot } \\
\text { Area }\end{array}$ & $\begin{array}{c}\text { Factor } \\
\text { (multiple of } \\
\text { authorized limit) }\end{array}$ \\
\hline$<1 \mathrm{~m}^{2}$ & $10^{\mathrm{a}}$ \\
$1-<3 \mathrm{~m}^{2}$ & 6 \\
$3-<10 \mathrm{~m}^{2}$ & 3 \\
$10-25 \mathrm{~m}^{2}$ & 2 \\
\hline \multicolumn{3}{|}{ Areas $<1 \mathrm{~m}^{2}$ are averaged over } \\
a $1-\mathrm{m}^{2}$ area; average shall not \\
exceed 10x the authorized limit.
\end{tabular}

Source: Yu et al. (1993b). 
TABLE 19 Residual Radioactive Material Guidelines for Radionuclides at OU IV Assuming a 100-Year Institutional Control Period Following Remedial Action

\begin{tabular}{lcccc}
\hline & \multicolumn{4}{c}{ Guidelines $^{\mathrm{a}}(\mathrm{pCi} / \mathrm{g})$} \\
\cline { 2 - 5 } \multicolumn{1}{c}{ Radionuclide } & Scenario $\mathrm{A}^{\mathrm{b}}$ & Scenario $\mathrm{B}^{\mathrm{b}}$ & Scenario $\mathrm{C}^{\mathrm{b}}$ & ${\text { Scenario } \mathrm{D}^{\mathrm{c}}}$ \\
\cline { 2 - 5 } Americium-241 & $1.9 \times 10^{2}$ & $4.0 \times 10^{2}$ & $6.1 \times 10^{1}$ & $1.3 \times 10^{2}$ \\
Cesium-137 & $2.9 \times 10^{2}$ & $6.6 \times 10^{2}$ & $9.6 \times 10^{1}$ & $3.0 \times 10^{2}$ \\
Cobalt-60 & $3.5 \times 10^{6}$ & $8.4 \times 10^{6}$ & $1.2 \times 10^{6}$ & $3.9 \times 10^{6}$ \\
Europium-152 & $3.0 \times 10^{3}$ & $7.4 \times 10^{3}$ & $1.0 \times 10^{3}$ & $3.4 \times 10^{3}$ \\
Europium-154 & $4.6 \times 10^{4}$ & $1.1 \times 10^{5}$ & $1.5 \times 10^{4}$ & $5.2 \times 10^{4}$ \\
Europium-155 & $1.0 \times 10^{9}$ & $2.5 \times 10^{9}$ & $3.4 \times 10^{8}$ & $1.1 \times 10^{9}$ \\
Plutonium-238 & $4.3 \times 10^{2}$ & $9.0 \times 10^{2}$ & $1.4 \times 10^{2}$ & $3.0 \times 10^{2}$ \\
Plutonium-239 & $1.8 \times 10^{2}$ & $3.7 \times 10^{2}$ & $5.7 \times 10^{1}$ & $1.2 \times 10^{2}$ \\
Plutonium-240 & $1.8 \times 10^{2}$ & $3.7 \times 10^{2}$ & $5.7 \times 10^{1}$ & $1.2 \times 10^{2}$ \\
Strontium-90 & $7.7 \times 10^{5}$ & $8.0 \times 10^{3}$ & $5.8 \times 10^{2}$ & $4.6 \times 10^{2}$ \\
Uranium-234 & $8.9 \times 10^{2}$ & $1.9 \times 10^{3}$ & $\mathrm{NA}$ & $\mathrm{NA}$ \\
Uranium-235 & $1.5 \times 10^{2}$ & $3.5 \times 10^{2}$ & $\mathrm{NA}$ & $\mathrm{NA}$ \\
Uranium-238 & $5.5 \times 10^{2}$ & $1.2 \times 10^{3}$ & $\mathrm{NA}$ & $\mathrm{NA}$ \\
\hline
\end{tabular}

a All values are reported to two significant figures.

b Based on a dose constraint of $30 \mathrm{mrem} / \mathrm{yr}$.

c Based on a dose limit of $100 \mathrm{mrem} / \mathrm{yr}$.

d $\mathrm{NA}=$ Not applicable. Maximum dose occurs after 400 years. Use the same guidelines as shown in Table 17. 


\section{REFERENCES}

BNL: See Brookhaven National Laboratory.

Brookhaven National Laboratory, 1994, Remedial Investigation Report-Operable Unit IV, Volume I, report 5101-001-DR-BBMZ (Draft), CDM Federal Programs Corporation, New York, Jan. 12.

DOE: See U.S. Department of Energy.

EPA: See U.S. Environmental Protection Agency.

International Technology Corp., 1991, Remedial Investigation/Feasibility Study Work Plan-Operable Unit IV, International Technology Corp., Torrance, Calif., Dec.

IT: See International Technology Corp.

Nealy, C.L., 1994, "RESRAD Analysis for Operable Unit IV at Brookhaven National Laboratory," letter from Nealy (DOE Brookhaven Area Office, Upton, N.Y.) to E.R. Faillace (Argonne National Laboratory, Argonne, Ill.), Sept. 9.

Penny, G., 1994, letter with attachments from Penny (Brookhaven National Laboratory, Upton, N.Y.) to E.R. Faillace (Argonne National Laboratory, Argonne, Ill.), Jan.

SAIC: See Science Applications International Corp.

Science Applications International Corp., 1992, Brookhaven National Laboratory Site Baseline Report-Volume I, Science Applications International Corp., San Diego, Calif., Jan.

U.S. Department of Energy, 1990, "Radiation Protection of the Public and Environment," DOE Order 5400.5, Washington, D.C., Feb. 8.

U.S. Environmental Protection Agency, 1990, Risk Assessment Guidance for Superfund, Volume I, Human Health Evaluation Manual, USEPA 540/1-89/002, Washington, D.C., Dec.

Warren, M.A., et al., 1963, Hydrology of Brookhaven National Laboratory and Vicinity Suffolk County, New York, Geological Survey Bulletin 1156-C, U.S. Department of the Interior, Washington, D.C.

Yu, C., et al., 1993a, Data Collection Handbook to Support Modeling the Impacts of Radioactive Material in Soil, ANL/EAIS-8, prepared by Argonne National Laboratory, Environmental Assessment and Information Sciences Division, Argonne, Ill., for U.S. Department of Energy, Office of Environmental Restoration, Washington, D.C., April.

Yu, C., et al., 1993b, Manual for Implementing Residual Radioactive Material Guidelines Using RESRAD, Version 5.0, ANL/EAD/LD-2, prepared by Argonne National Laboratory, Environmental Assessment Division, Argonne, Ill., for U.S. Department of Energy, Office of Environmental Restoration, Washington, D.C., Sept. 


\section{APPENDIX \\ SCENARIOS AND PARAMETERS USED FOR THE ANALYSIS OF OPERABLE UNIT IV AT BROOKHAVEN NATIONAL LABORATORY}

The following exposure scenarios were analyzed for OU IV:

- Scenario A: Industrial Use of the Site. A hypothetical person is assumed to work in the area of the site.

- Scenario B: Recreational Use of the Site. A hypothetical person is assumed to use the site for recreational purposes and for hunting.

- Scenario C: Residential Use of the Site. A hypothetical resident is assumed to live in the decontaminated area and to use an on-site water well for drinking and irrigation. The resident is assumed to ingest plant foods grown on-site; however, no livestock is raised for the production of meat and milk, and no pond is present on-site to provide fish and other aquatic food.

- Scenario D: Agricultural Use of the Site. A hypothetical farmer is assumed to live in the decontaminated area and to use water from an on-site well for drinking, livestock watering, and irrigation. The resident is assumed to ingest plant foods grown on the farm and meat and milk from livestock fed with forage grown on-site. No pond is present on-site to provide fish and other aquatic organisms.

The parametric values used in the RESRAD code for the analysis of OU IV are listed in Table A.1. All parametric values are reported at up to three significant figures. Some parameters are specific to OU IV; other values are generic. 
TABLE A.1 Parameters Used in the RESRAD Computer Code for the Analysis of Operable Unit IV at Brookhaven National Laboratory

\begin{tabular}{|c|c|c|c|c|c|}
\hline \multirow[b]{2}{*}{ Parameter } & \multirow[b]{2}{*}{ Unit } & \multicolumn{4}{|c|}{ Value } \\
\hline & & Scenario A & Scenario B & Scenario C & Scenario D \\
\hline Area of contaminated zone $\mathrm{e}^{\mathrm{a}}$ & $\mathrm{m}^{2}$ & 3,100 & 3,100 & 3,100 & 3,100 \\
\hline Thickness of contaminated zone $e^{a}$ & $\mathbf{m}$ & 7.9 & 7.9 & 7.9 & 7.9 \\
\hline Length parallel to aquifer flow ${ }^{\mathrm{a}}$ & m & Not used & 55 & 55 & 55 \\
\hline Basic radiation dose limit ${ }^{a, b}$ & mrem/yr & 30 & 30 & 30 & 100 \\
\hline Cover depth ${ }^{a}$ & m & 0 & 0 & 0 & 0 \\
\hline \multicolumn{6}{|l|}{ Contaminated zone } \\
\hline Density & $\mathrm{g} / \mathrm{cm}^{3}$ & 2 & 2 & 2 & 2 \\
\hline Erosion rate & $\mathrm{m} / \mathrm{yr}$ & 0.001 & 0.001 & 0.001 & 0.001 \\
\hline Total porosity & $-c$ & 0.33 & 0.33 & 0.33 & 0.33 \\
\hline Effective porosity & - & 0.24 & 0.24 & 0.24 & 0.24 \\
\hline Hydraulic conductivity & $\mathrm{m} / \mathrm{yr}$ & 5,000 & 5,000 & 5,000 & 5,000 \\
\hline Soil-specific b parameter ${ }^{\mathrm{a}}$ & $-c$ & 4.9 & 4.9 & 4.9 & 4.9 \\
\hline Evapotranspiration coefficient $t^{\mathbf{a}}$ & $-\sim^{c}$ & 0.46 & 0.46 & 0.46 & 0.46 \\
\hline Precipitation $^{\mathrm{a}}$ & $\mathrm{m} / \mathrm{yr}$ & 1.10 & 1.10 & 1.10 & 1.10 \\
\hline Irrigation ${ }^{a}$ & $\mathrm{~m} / \mathrm{yr}$ & 0.26 & 0.26 & 0.26 & 0.26 \\
\hline Irrigation mode $\mathrm{e}^{\mathrm{b}}$ & $-c$ & Overhead & Overhead & Overhead & Overhead \\
\hline Runoff coefficient ${ }^{b}$ & $-c$ & 0.2 & 0.2 & 0.2 & 0.2 \\
\hline Watershed area for nearby pond $d^{\mathrm{a}, \mathrm{b}}$ & $\mathrm{m}^{2}$ & Not used & $1,000,000$ & Not used & Not used \\
\hline Accuracy for water/soil computation ${ }^{\mathrm{a}, \mathrm{b}}$ & $-c$ & Not used & 0.001 & 0.001 & 0.001 \\
\hline \multicolumn{6}{|l|}{ Saturated zone } \\
\hline Density ${ }^{\mathrm{B}}$ & $\mathrm{g} / \mathrm{cm}^{3}$ & Not used & 2.0 & 2.0 & 2.0 \\
\hline Total porosity ${ }^{\mathrm{a}}$ & - & Not used & 0.33 & 0.33 & 0.33 \\
\hline Effective porosity & $-c$ & Not used & 0.24 & 0.24 & 0.24 \\
\hline Hydraulic conductivity & $\mathrm{m} / \mathbf{y r}$ & Not used & 20,000 & 20,000 & 20,000 \\
\hline Hydraulic gradient ${ }^{\mathrm{a}}$ & $-c$ & Not used & 0.001 & 0.001 & 0.001 \\
\hline Soil-specific b parameter ${ }^{a}$ & $-\mathbf{c}$ & Not used & 4.9 & 4.9 & 4.9 \\
\hline Water table drop rate $\mathrm{e}^{\mathrm{a}, \mathrm{b}}$ & $\mathrm{m} / \mathrm{yr}$ & Not used & 0.001 & 0.001 & 0.001 \\
\hline Well pump intake depth (below water table) ${ }^{\mathrm{a}}$ & m & Not used & Not used & 18 & 18 \\
\hline $\begin{array}{l}\text { Model: nondispersion (ND) or mass } \\
\text { balance }(\mathrm{MB})^{\mathrm{b}}\end{array}$ & $-c$ & Not used & ND & ND & ND \\
\hline Well pumping rate $e^{a, b}$ & $\mathrm{~m}^{3} / \mathrm{yr}$ & Not used & Not used & 250 & 250 \\
\hline Number of unsaturated zone strata ${ }^{b}$ & $-c^{c}$ & Not used & 1 & 1 & 1 \\
\hline \multicolumn{6}{|l|}{ Unsaturated zone } \\
\hline Thickness $^{a}$ & $\mathbf{m}$ & Not used & 2.7 & 2.7 & 2.7 \\
\hline Soil density ${ }^{2}$ & $\mathrm{~g} / \mathrm{cm}^{3}$ & Not used & 2.0 & 2.0 & 2.0 \\
\hline Total porosity ${ }^{a}$ & $-c^{c}$ & Not used & 0.33 & 0.33 & 0.33 \\
\hline Effective porosity & $-c$ & Not used & 0.24 & 0.24 & 0.24 \\
\hline Soil-specific b parameter ${ }^{\mathrm{z}}$ & $-c$ & Not used & 4.9 & 4.9 & 4.9 \\
\hline Hydraulic conductivity ${ }^{\mathrm{a}}$ & $\mathrm{m} / \mathrm{yr}$ & Not used & 5,000 & 5,000 & 5,000 \\
\hline \multicolumn{6}{|l|}{ Distribution coefficient (all zones) } \\
\hline Am-241 & & 1,900 & 1,900 & 1,900 & 1,900 \\
\hline Cs-137 & & 280 & 280 & 280 & 280 \\
\hline $\mathrm{Co}-60$ & & 60 & 60 & 60 & 60 \\
\hline Eu-152 & & $580^{\circ}$ & $580^{\circ}$ & $580^{\mathrm{e}}$ & $580^{\mathrm{e}}$ \\
\hline Eu-154 & & $580^{\mathrm{e}}$ & $580^{e}$ & $580^{\circ}$ & $580^{\circ}$ \\
\hline Eu-155 & & $580^{\circ}$ & $580^{\circ}$ & $580^{\mathrm{e}}$ & $580^{\circ}$ \\
\hline Pu-238 & & 550 & 550 & 550 & 550 \\
\hline Pu-239 & & 550 & 550 & 550 & 550 \\
\hline $\mathrm{Pu}-240$ & & 550 & 550 & 550 & 550 \\
\hline Sr-90 & & 15 & 15 & 15 & 15 \\
\hline U-234 & & 35 & 35 & 35 & 35 \\
\hline U-235 & & 35 & 35 & 35 & 35 \\
\hline U-238 & & 35 & 35 & 35 & 35 \\
\hline Ac- $227^{\complement}$ & & 450 & 450 & 450 & 450 \\
\hline $\mathrm{Gd}-152^{\mathrm{f}}$ & & $580^{\circ}$ & $580^{\mathrm{B}}$ & $580^{\circ}$ & $580^{\mathrm{e}}$ \\
\hline
\end{tabular}


TABLE A.1 (Cont.)

\begin{tabular}{|c|c|c|c|c|c|}
\hline \multirow[b]{2}{*}{ Parameter } & \multirow[b]{2}{*}{ Unit } & \multicolumn{4}{|c|}{ Value } \\
\hline & & Scenario A & Scenario B & Scenario C & Scenario D \\
\hline \multicolumn{6}{|l|}{ Distribution coefficient (all zones) (cont.) } \\
\hline $\mathrm{Np}-237^{\mathrm{f}}$ & & $\mathbf{5}$ & 5 & 5 & 5 \\
\hline $\mathrm{Pa}-231^{\mathrm{f}}$ & & 550 & 550 & 550 & 550 \\
\hline $\mathrm{Pb}-210^{\mathrm{F}}$ & & 270 & 270 & 270 & 270 \\
\hline $\operatorname{Ra}-226^{\mathrm{f}}$ & & 500 & 500 & 500 & 500 \\
\hline $\operatorname{Ra}-228^{f}$ & & 500 & 500 & 500 & 500 \\
\hline Th $-228^{f}$ & & 3,200 & 3,200 & 3,200 & 3,200 \\
\hline Th-229f & & 3,200 & 3,200 & 3,200 & 3,200 \\
\hline Th-230 & & 3,200 & 3,200 & 3,200 & 3,200 \\
\hline Th-232 & & 3,200 & 3,200 & 3,200 & 3,200 \\
\hline$U-233^{f}$ & & 35 & 35 & 35 & 35 \\
\hline $\mathrm{U}-236^{\mathrm{i}}$ & & 35 & 35 & 35 & 35 \\
\hline Inhalation rate $\mathrm{e}^{\mathrm{b}}$ & $\mathrm{m}^{3} / \mathrm{yr}$ & 7,300 & 7,300 & 7,300 & 7,300 \\
\hline Mass loading for inhalation ${ }^{b}$ & $\mathrm{~g} / \mathrm{m}^{3}$ & 0.0002 & 0.0002 & 0.0002 & 0.0002 \\
\hline Shielding factor, inhalation ${ }^{\mathrm{b}}$ & $-c$ & 0.4 & 0.4 & 0.4 & 0.4 \\
\hline Shielding factor, external gamma ${ }^{a}$ & $-{ }^{\mathfrak{c}}$ & 0.8 & 0.8 & 0.8 & 0.8 \\
\hline Fraction of time indoors $\mathrm{s}^{\mathrm{a}, \mathrm{b}}$ & $-c$ & 0.06 & 0 & 0.5 & 0.5 \\
\hline Fraction of time outdoors $\mathrm{s}^{\mathrm{a}, \mathrm{b}}$ & $-c$ & 0.17 & 0.09 & 0.25 & 0.25 \\
\hline Shape factor, external gamma ${ }^{b}$ & $-{ }^{c}$ & 1 & 1 & 1 & 1 \\
\hline Dilution length for airborne dust, inhalation ${ }^{b}$ & $\mathrm{~m}$ & 3 & 3 & 3 & 3 \\
\hline \multicolumn{6}{|l|}{ Food consumption } \\
\hline Fruits, vegetables, and grain ${ }^{\mathrm{a}, \mathrm{b}}$ & $\mathrm{kg} / \mathrm{yr}$ & Not used & Not used & 160 & 160 \\
\hline Leafy vegetables ${ }^{a, b}$ & $\mathrm{~kg} / \mathrm{yr}$ & Not used & Not used & 14 & 14 \\
\hline Milk $^{a, b}$ & $\mathrm{~L} / \mathrm{yr}$ & Not used & Not used & Not used & 92 \\
\hline Meat and poultry ${ }^{a, b}$ & $\mathrm{~kg} / \mathrm{yr}$ & Not used & 63 & Not used & 63 \\
\hline Soil ingestion ${ }^{\mathrm{a}, \mathrm{b}}$ & $\mathrm{g} / \mathrm{yr}$ & 36.5 & 43.8 & 43.8 & 43.8 \\
\hline Drinking water intake ${ }^{a}$ & $\mathrm{~L} / \mathrm{yr}$ & Not used & Not used & 700 & 700 \\
\hline \multicolumn{6}{|l|}{ Contaminated fraction of food and water } \\
\hline Drinking water ${ }^{a, b}$ & & Not used & Not used & 1 & 1 \\
\hline Household water ${ }^{a, b}$ & & Not used & Not used & 1 & 1 \\
\hline Livestock water $^{\mathbf{a}, \mathbf{b}}$ & & Not used & 1 & Not used & 1 \\
\hline Irrigation water ${ }^{\mathrm{a}, \mathrm{b}}$ & & 0 & 0 & 1 & 1 \\
\hline Plant food $d^{a, b}$ & & Not used & Not used & 0.1 & $0.5^{\mathrm{d}}$ \\
\hline Meat $^{\mathrm{a}, \mathrm{b}}$ & & Not used & 0.1 & Not used & $0.155^{\mathrm{d}}$ \\
\hline Milk $^{\mathrm{a}, \mathrm{b}}$ & & Not used & Not used & Not used & $0.155^{\mathrm{d}}$ \\
\hline Livestock fodder intake for meat $t^{a, b}$ & $\mathrm{~kg} / \mathrm{d}$ & Not used & 68 & Not used & 68 \\
\hline Livestock fodder intake for millk ${ }^{a, b}$ & $\mathrm{~kg} / \mathrm{d}$ & Not used & Not used & Not used & 55 \\
\hline Livestock water intake for meat ${ }^{a, b}$ & $\mathrm{~L} / \mathrm{d}$ & Not used & 50 & Not used & 50 \\
\hline Livestock water intake for milk ${ }^{\mathrm{a}, \mathrm{b}}$ & $\overline{\mathrm{L} / \mathrm{d}}$ & Not used & Not used & Not used & 160 \\
\hline Livestock soil intake ${ }^{\mathrm{a}, \mathrm{b}}$ & $\mathbf{k g} / \mathrm{d}$ & Not used & 0.5 & Not used & 0.5 \\
\hline Mass loading for foliar deposition ${ }^{\mathrm{a}, \mathrm{b}}$ & $\mathrm{g} / \mathrm{m}^{3}$ & Not used & 0.0001 & 0.0001 & 0.0001 \\
\hline Depth of soil mixing layer & $\mathrm{m}$ & 0.15 & 0.15 & 0.15 & 0.15 \\
\hline Depth of roots $\mathrm{s}^{\mathrm{a}, \mathrm{b}}$ & $\mathbf{m}$ & Not used & 0.9 & 0.9 & 0.9 \\
\hline \multicolumn{6}{|l|}{$\begin{array}{l}\text { Groundwater fractional usage (balance } \\
\text { from surface water) }\end{array}$} \\
\hline Drinking water ${ }^{\mathrm{a}, \mathrm{b}}$ & $-c$ & Not used & Not used & 1 & 1 \\
\hline Household water ${ }^{a, b}$ & & Not used & Not used & 1 & 1 \\
\hline Livestock water ${ }^{a, b}$ & & Not used & 0 & 1 & 1 \\
\hline Irrigation $^{\mathrm{a}, \mathrm{b}}$ & & Not used & Not used & 1 & 1 \\
\hline Storage times of contaminated foodstuffs & days & & & & \\
\hline Fruits, nonleafy vegetables, and grain ${ }^{a, b}$ & & Not used & Not used & 14 & 14 \\
\hline Leafy vegetables ${ }^{\mathrm{a}, \mathrm{b}}$ & & Not used & Not used & 1 & 1 \\
\hline Milk $^{\mathrm{a}, \mathrm{b}}$ & & Not used & Not used & Not used & 1 \\
\hline Meat and poultry & & Not used & 20 & Not used & 20 \\
\hline Well water ${ }^{a, b}$ & & Not used & Not used & 1 & 1 \\
\hline Surface water ${ }^{a, b}$ & & Not used & 1 & Not used & Not used \\
\hline Livestock fodder ${ }^{a, b}$ & & Not used & 45 & Not used & 45 \\
\hline
\end{tabular}


TABLE A1 (Cont.)

\begin{tabular}{|c|c|c|c|c|c|}
\hline \multirow[b]{2}{*}{ Parameter } & \multirow[b]{2}{*}{ Unit } & \multicolumn{4}{|c|}{ Value } \\
\hline & & Scenario A & Scenario B & Scenario C & Scenario D \\
\hline $\begin{array}{l}\text { Total porosity of the house or building } \\
\text { foundation }{ }^{\mathrm{a}, \mathrm{b}}\end{array}$ & $-c$ & 0.1 & Not used & 0.1 & 0.1 \\
\hline Volumetric water content of the foundation ${ }^{a, b}$ & - & 0.03 & Not used & 0.03 & 0.03 \\
\hline Diffusion coefficient for radon gas & $\mathrm{m}^{2} / \mathrm{s}$ & & & & \\
\hline In foundation material ${ }^{a, b}$ & & $3.0 \times 10^{-7}$ & Not used & $3.0 \times 10^{-7}$ & $3.0 \times 10^{-7}$ \\
\hline In contaminated soil ${ }^{\mathrm{b}}$ & & $2.0 \times 10^{-6}$ & $2.0 \times 10^{-6}$ & $2.0 \times 10^{-6}$ & $2.0 \times 10^{-6}$ \\
\hline Emanating power of radon- $222^{\text {b }}$ & $-c$ & 0.25 & 0.25 & 0.25 & 0.25 \\
\hline Emanating power of radon- $220^{b}$ & & 0.15 & 0.15 & 0.15 & 0.15 \\
\hline Radon vertical dimension of mixing & $\mathbf{m}$ & 2 & 2 & 2 & 2 \\
\hline Average annual wind speed ${ }^{b}$ & $\mathrm{~m} / \mathrm{s}$ & 2 & 2 & 2 & 2 \\
\hline Average building air exchange rate $e^{a, b}$ & $1 / \mathrm{h}$ & 0.5 & Not used & 0.5 & 0.5 \\
\hline Height of building (room) $)^{a, b}$ & $\mathrm{~m}$ & 2.5 & Not used & 2.5 & 2.5 \\
\hline Building indoor area factor ${ }^{\mathrm{a}, \mathrm{b}}$ & $-c$ & 0 & Not used & 0 & 0 \\
\hline Bulk density of house or building foundation ${ }^{a, b}$ & $\mathrm{~g} / \mathrm{cm}^{3}$ & 2.4 & Not used & 2.4 & 2.4 \\
\hline Thickness of house or building foundation ${ }^{a, b}$ & $\mathbf{m}$ & 0.15 & Not used & 0.15 & 0.15 \\
\hline Building depth below ground surface ${ }^{a, b}$ & $\mathrm{~m}$ & 1 & Not used & 1 & 1 \\
\hline
\end{tabular}

a Values based on site specifications, scenario assumptions, and Manual for Implementing Residual Radioactive Material Guidelines Using RESRAD, Version 5.0 (C. Yu et al., 1993, report ANL/EAD/LD-2, prepared by Argonne National Laboratory, Argonne, Ill., for U.S. Department of Energy, Office of Environmental Restoration, Washington, D.C., Sept.).

b RESRAD default values.

- Parameter is dimensionless.

d Calculated with the RESRAD computer code.

e Distribution coefficient calculated by RESRAD using the soil/plant transfer factor.

f Radioactive progeny with half-lives $>6$ months. 